AN URBAN PLANNING PERSPECTIVE ON PLANNING TO ADDRESS THE NEEDS

AND CAPABILITIES OF A GROWING SENIORS POPULATION: AN

INVESTIGATION OF THE SENIOR FRIENDLY COMMUNITIES APPROACH

\author{
by \\ Brahm Levine \\ B.A., Urban Studies, Concordia University, 2011
}

\author{
A MRP, \\ presented to Ryerson University \\ in partial fulfillment of the \\ requirements for the degree of \\ Master of Planning \\ in Urban Development
}

Toronto, Ontario, Canada, 2013

(C)Brahm Levine 2013 


\section{Author's Declaration}

I hereby declare that I am the sole author of this MRP. This is a true copy of the MRP, including any required final revisions.

I authorize Ryerson University to lend this MRP to other institutions or individuals for the purpose of scholarly research

I further authorize Ryerson University to reproduce this MRP by photocopying or by other means, in total or in part, at the request of other institutions or individuals for the purpose of scholarly research.

I understand that my MRP may be made electronically available to the public. 


\title{
AN URBAN PLANNING PERSPECTIVE ON PLANNING TO ADDRESS THE NEEDS AND CAPABILITIES OF A GROWING SENIORS POPULATION: AN INVESTIGATION OF THE SENIOR FRIENDLY COMMUNITIES APPROACH
}

\author{
Master of Planning in the Program of \\ Urban Development \\ Brahm Levine \\ Ryerson University, 2013
}

\begin{abstract}
This research examines the aging population and explores how the urban built environment should be transformed to be friendlier to seniors. Rapidly approaching, an unprecedented shift in demographics will significantly increase the proportion of the seniors' population. Their changing needs and capabilities will pose accessibility issues within the built environment. A case study of the waterfront neighbourhood of Port Credit in Mississauga, Ontario will be used, as an example of a local aging population. By studying policy documents, a recent mixed-use development, site visits, and interviewing key informants, it was found that dense, compact and transit-oriented developments (TODs) that are walkable, allow seniors to age- in-place better, compared to the traditional neighbourhood design. In Summary, this research reveals that by making the urban built environment more walkable, and accessible, seniors can be more independent, safer and better be integrated into the community for a longer time.
\end{abstract}




\section{Acknowledgements}

I can still remember being taken out of class in elementary school for "remediation" sessions, endless afternoons and evenings spent with tutors and even having to take a supplemental test to be accepted into the private high school I attended. The truth is, I have had my fair share of difficulties and setbacks throughout my academic career and I could not have made it to where I am today with out the never-ending love and support of my parents Barbara and Saul Levine. I thank you both from the bottom of my heart for all that you have allowed, and done for me, over the past 25 years.

I would also like to take the opportunity to thank my supervisor Dr. Joseph Springer and advisor Dr. Christian Fisker for their guidance over the past year. Dr. Fisker, your optimism and forever supportive outlook helped me more than you will ever know, and for that, I thank you.

To all those who contributed in any capacity, whether it be reviewing rough drafts or donating their time for interviews and general questions, you know who you are and I sincerely believe that this paper would not have turned out the way it has without all your contributions.

Lastly, I would like to thank my colleagues in the 2013 Master of Planning cohort. I look back on the past two years to be some of the best years of my life. I consider you all friends and appreciate all your encouragement and kind words along the way. 


\section{Table of Contents}

Author's Declaration.......................................................................................................... ii

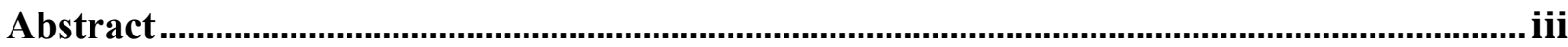

Acknowledgements .............................................................................................................. iv

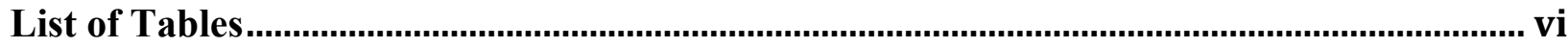

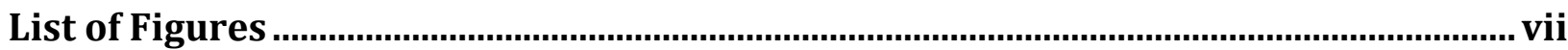

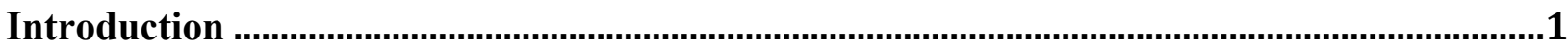

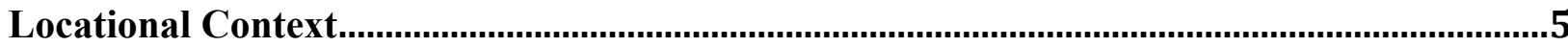

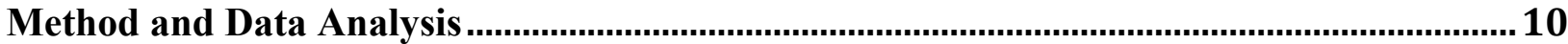

Literature Review ….................................................................................................. 13

Housing and Access to Services That Address Seniors' Needs ............................................................ 13

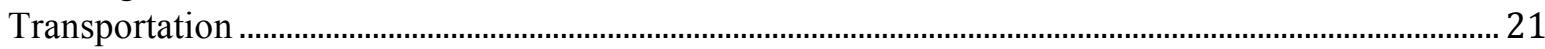

Public Space

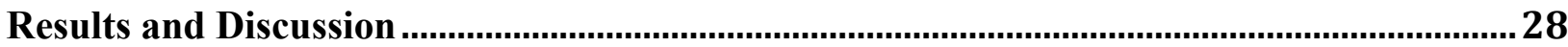

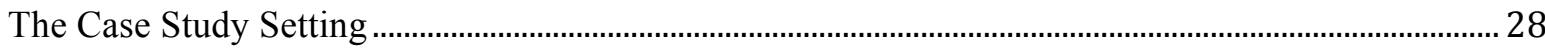

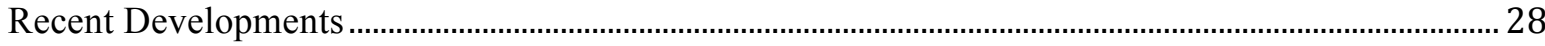

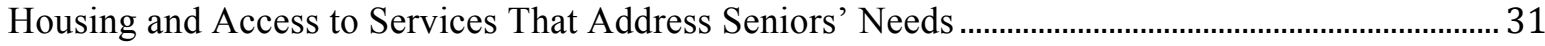

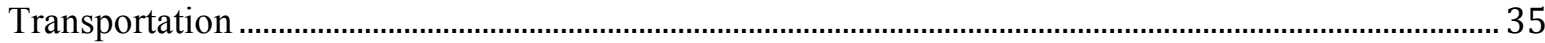

Public Space

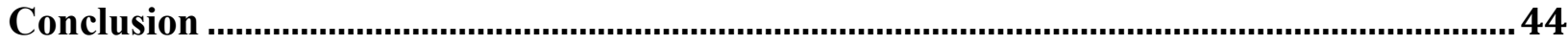

Lessons Learned \& Recommendations ............................................................................45

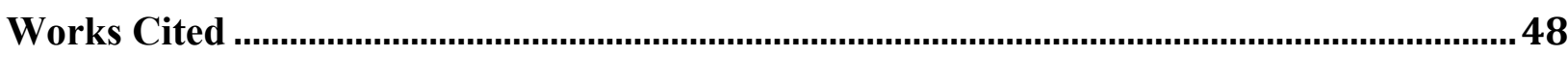

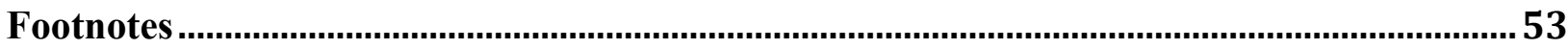




\section{List of Tables}

Table 1: Port Credit Population Change, 1996-2011 _.........................................................

Table 2: Population Projections for the Region of Peel, 2011-2036 ................................ 


\section{List of Figures}

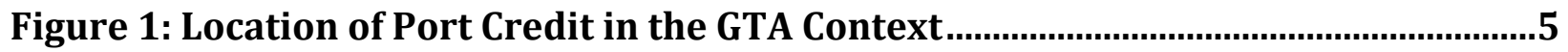

Figure 2: Port Credit Neighbourhood Land Use Map ........................................................6

Figure 3: The Senior Population (Age 65+ Years) by Peel Neighbourhoods, 2006 ........8

Figure 4: Peel's Population Distribution of Adults 55 Years or Older .............................9

Figure 5: Port Credit Village Transportation Map ...............................................................28

Figure 6: Port Credit Village Master Plan (Phase 1)..........................................................29

Figure 7: Other Relevant Growth Plan Policies....................................................................30

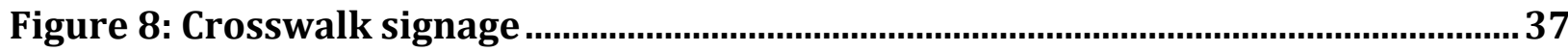

Figure 9: Seating space at a bus shelter on Lakeshore Road East ....................................39

Figure 10: Benches on the Waterfront Trail ........................................................................39

Figure 11: Benches provided at Harold E. Kennedy Park. ………......................................40

Figure 12: Waterfront trail .........................................................................................41

Figure 13. Accessible ramp design at intersection of Lakeshore Road East and

Elmwood Avenue North .......................................................................................................42 


\section{Introduction}

There is an unprecedented change in the global demographic make-up headed our way in the foreseeable future that we, as a society, must prepare for. Some have referred to it as a tsunami (Kennedy, 2010) or an age-wave (Dychwald \& Flower, 1990) and others a boom (Foot, 1990). Regardless of its name, it is widely believed that the aging population in developed countries will experience a staggering increase in both proportion of the entire population as well as in absolute numbers (Scharlach, 2009; World Health Organization, 2007; Hodge, 2008, United Nations for Human Settlements, 1993; Rosenbloom, 2003; Plouffe \& Kalache, 2010 etc.). Moreover, the development of cities in the post WWII era has led many to argue that the current built environment is not suited to meet the changing needs of seniors ${ }^{1}$ (Pynoos, Caraviello \& Cicero, 2009; Scharlach, 2009, Holeywell, 2012; Kennedy, 2003). Generally speaking, as this demographic group ages they will undergo changes that will limit their physical and mental abilities, and will thus make living in the current urban built environment significantly more challenging.

There are already a few age-friendly initiatives present in Ontario, such as in Hamilton (Hamilton Council on Aging, 2010) and in Burlington (Burlington Senior Age Friendly Task Force, 2009). The research question for this paper asks how is the City of Mississauga Ontario modifying its urban built environments to be more senior friendly? More specifically this research question will focus on the waterfront community of Port Credit. The World Health

\footnotetext{
${ }^{1}$ The term 'senior' is not a descriptive term for a homogenous group. Statistics Canada, (2012) provides sub categories for 'Pre-seniors - aged 55 to 64', 'Young seniors - aged 65-74', 'Older seniors - aged 75 to 84' and 'Eldest seniors - aged 85+'.
} 
Organization (WHO) document, Global Age-friendly-Cities: A Guide (2007) forms the framework for this research. This checklist identifies eight particular domains of age friendly cities, these being transportation, housing, outdoor spaces and buildings, community and health services, communication and information, civic participation and employment, respect and social inclusion and social participation. The document also identifies a check list of criteria that each domain should meet. Of the wide-ranging areas, this paper will focus on housing, transportation and public spaces; specifically, how these uses can be modified to make the urban built environment friendlier, or more accommodating, to seniors with changing needs and capabilities.

The Port Credit neighbourhood of the City of Mississauga within the Greater Toronto Area is used as a case study in this research paper. This urban village has a significant proportion of older residents, making it an early example of an aging population in a suburban context. The increase in the aging of the population will undoubtedly be experienced by many other suburbs in the Greater Toronto Area (GTA) in the years to come, and insights learned here may prepare other communities for an aging population. Also, developments within Mississauga have recently incorporated elements of Transit Oriented Development (TOD) (CMHC, 2007), which also makes it a prime study location for this research.

A basic literature review, incorporating information derived from scholarly journals, Canada Mortgage and Housing Corporation reports, and other government documents, provides thorough analysis on how over the past twenty-odd years local governments have been attempting to make their urban built environments more senior friendly. Furthermore, key informant interviews provide more detailed and rich information from the perspective of city 
planners and other municipal employees and developers of local housing initiatives, on how the built environment can and should be adapted to meet the needs of this particular aging cohort.

This paper begins with the Introduction, which provides a general overview and outlines the specific research question. This section also outlines the areas that will be focused on towards addressing the research question. The following section, Locational Context, will introduce the specific area of study and provide the reader with a better understanding of the history and current context of the area if one is unfamiliar with the area. Following the locational context is the Method and Data Analysis section, which explains the research process.

The next portion of the research paper is the Literature Review, which familiarizes the reader with the topic of senior friendly communities and what has been discussed in the literature in terms of housing, transportation and public spaces. As was alluded to in the previous paragraph, the WHO Global Age-Cities guide will frame this research. More specifically, with regards to the section on housing, resource documents are from CMHC $(2008 ; 2012)$ and American Association for Retired Persons (AARP) (2005) with pertinent data on seniors' housing trends and preferences. Other sources will provide information on design and modifications that can help seniors age-in-place, among various other sub topics related to housing (Holeywell, 2012; Scharlach, 2009; Pynoos, Caraviello and Cicero, 2009; Government of Australia, 2011; Hodge, 2008).

The section discussing transportation will be guided by authors such as Rosenbloom (2008), Stromberg (2007) and Fisker $(2011 ; 2012)$ in discussing mobility issues, primary modes 
of transport used by seniors, public transportation use and trends, in addition to neighbourhood walkability, city design and smart growth. The final segment focusing on public space will discuss the public space throughout cities and how they can be reconfigured in terms of making public spaces more accessible to seniors. Using the WHO (2007) guide in addition to the United Nations Centre for Human Settlements (UNCHS) (1993) and various other sources, the research paper investigates how the design and use of elements such as sidewalks, public benches, public toilets, green space and clean and safe environments, among other topics, can affect the quality and usability of public spaces for the senior population.

This paper will come to a close with a conclusion paragraph, summarizing the findings and answering the research question. Finally, the last section is a set of recommendations, providing suggestions for the municipality of Mississauga and the neighbourhood of Port Credit, in addition to other municipalities, on how to continue in their attempts at transforming their urban built environments to better accommodate seniors. 


\section{Locational Context}

The Region of Peel is one of five regional municipalities comprising the Greater Toronto Area (GTA). Located to the west of the City of Toronto, Peel is comprised of three local municipalities, these being Caledon, Brampton and Mississauga. The focus of this paper, as stated in the previous section, is the Port Credit neighbourhood located in Mississauga. The neighbourhood is a waterfront community located at the mouth of the Credit River in the southernmost part of the City, abutting Lake Ontario (See Figure 1).

Figure 1: Location of Port Credit in the GTA Context

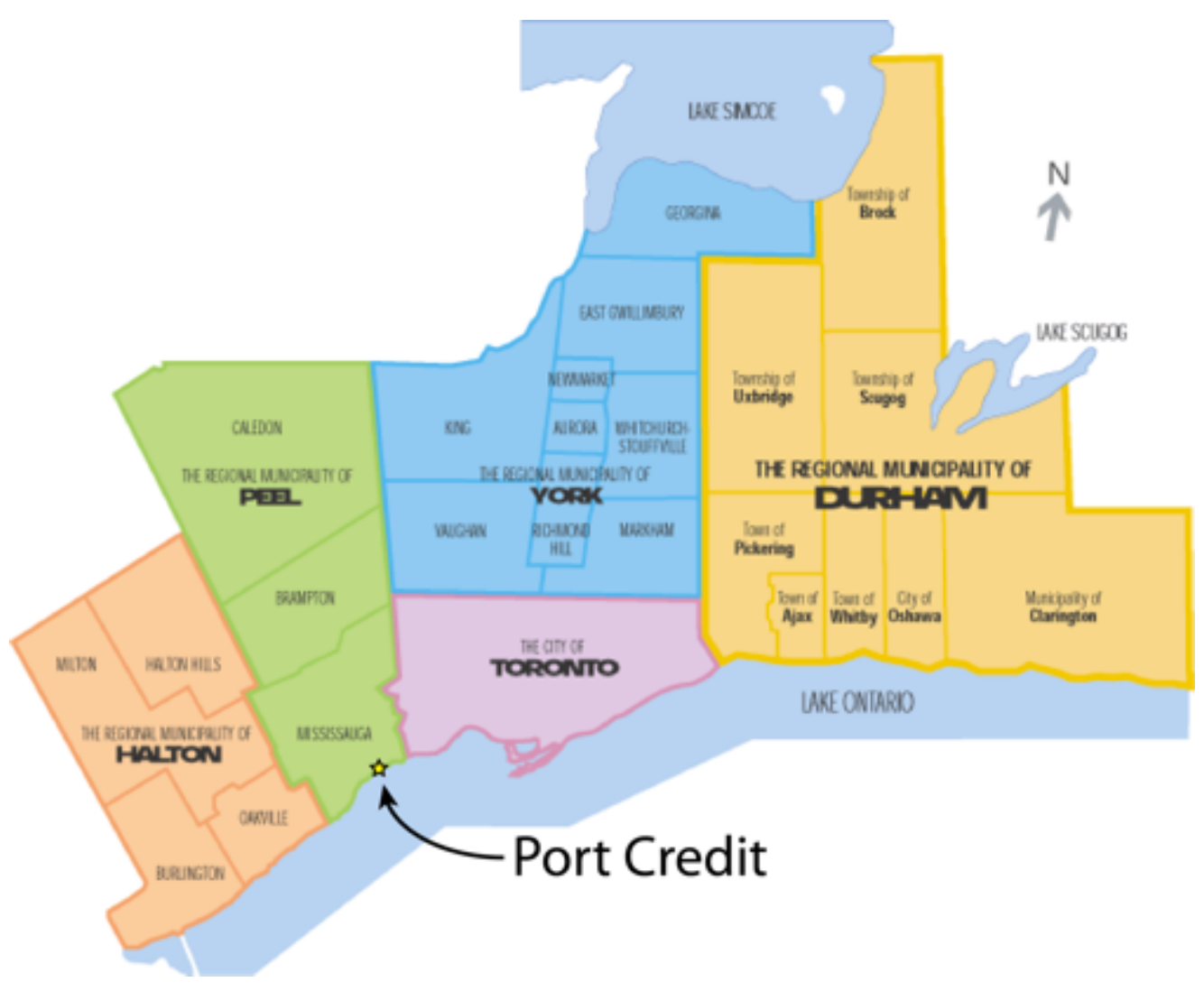

Source: City-data (2013) - Manipulated by Levine, B. 
In terms of a planning context, the area was first surveyed in 1834 and the settlement was laid out to the west of the Credit River (City of Mississauga, 2012). The area was eventually incorporated as its own town, in 1961 but was later amalgamated into the City of Mississauga in 1974 (City of Mississauga, 2004). Due to its strategic waterfront location, and as its name suggests, the area has a history rooted in its port function and was even used as a trading post by the British for the fur trade as far back as 1798 (Heritage Mississauga, 2009). Over the years the town has been home to several industries such as a charter fishing center, an oil refinery, the St. Lawrence Starch Works and a landfill. Presently, Port Credit is characterized by stable residential neighbourhoods, with an array of dwelling types and forms, linked by a commercial corridor (City of Mississauga, 2012) (see figure 2).

Figure 2: Port Credit Neighbourhood Land Use Map

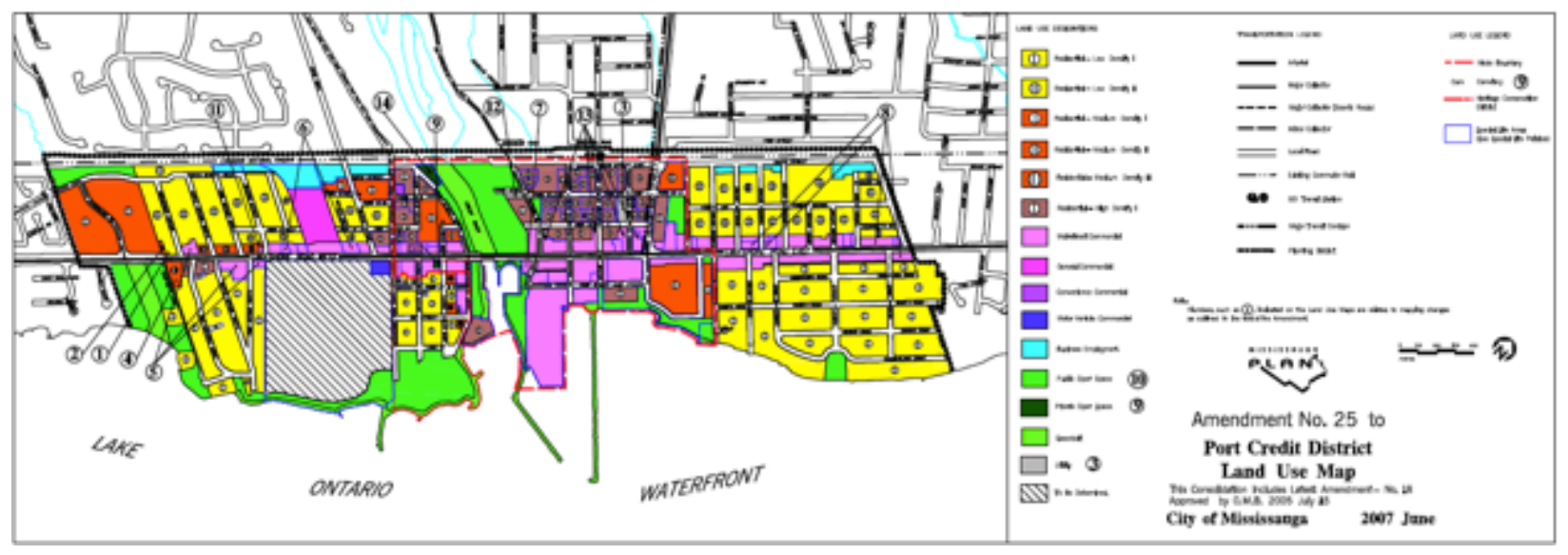

(Source: City of Mississauga, 2007)

Over the past 15 years the neighbourhood has experienced a $4.74 \%$ net increase of population where today it stands at 10,540 residents, representing $1.48 \%$ of the population of Mississauga. With an area of three square kilometers, the neighbourhood has a population density of 4,008 residents per square kilometer. Taken alone, this might not say that much, but 
when compared to Mississauga as a whole with a population density of 2,440 residents per square kilometer and the Region of Peel with 1,040 residents per square kilometer, it demonstrates that this particular location is relatively dense (Statistics Canada, 1996, 2001, 2006, $2011)^{2}$. There has also been a change in the demographic composition over the last fifteen years. As can be seen from table 1, there has been a trend where the population aged 44 years old and younger has been steadily decreasing, while the proportion of population nearing the age of retirement and above has been on the rise. More evidence can be seen through figure 3 , where it is clearly illustrated that there is a significant senior population in Port Credit and its adjacent neighbourhoods.

Table 1: Port Credit Population Change, 1996-2011

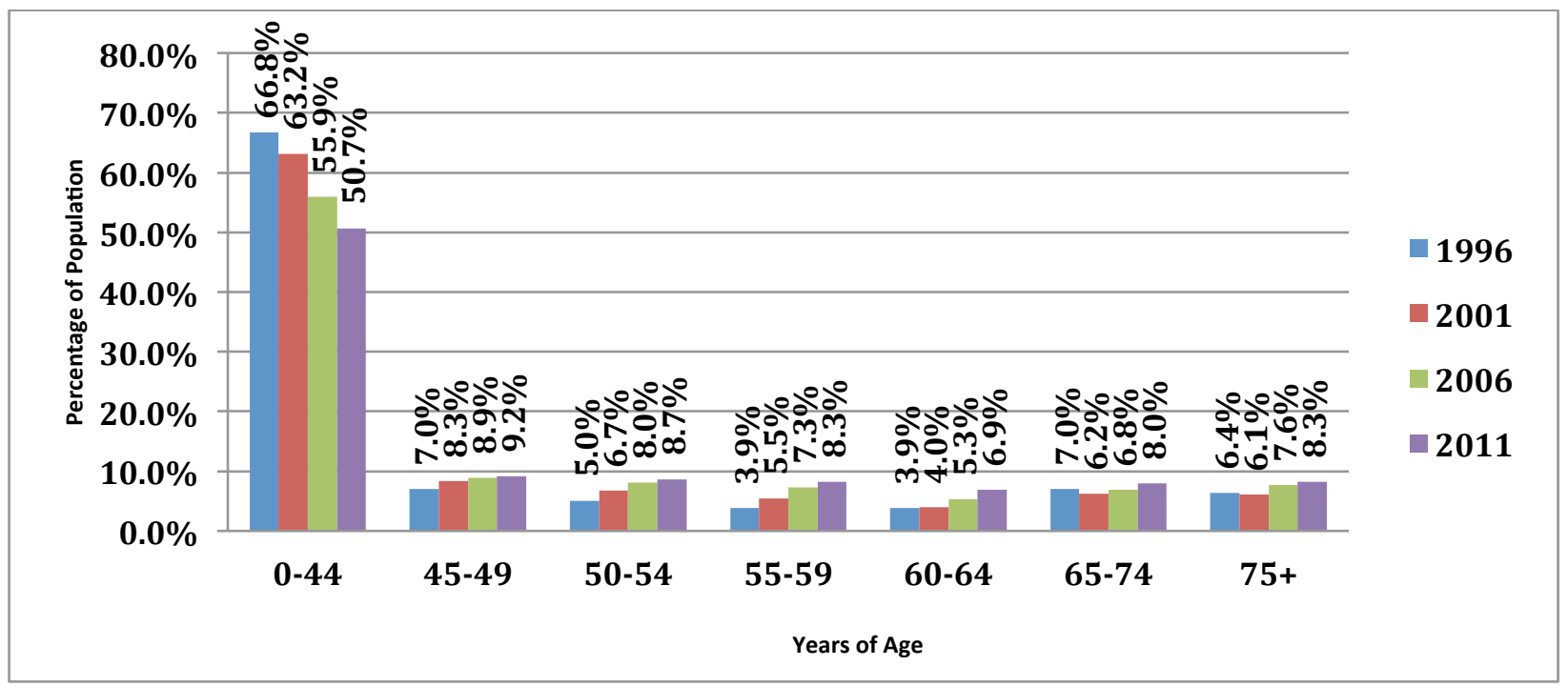

Source: Statistics Canada: 2006,2011; City of Mississauga 1999, 2004

\footnotetext{
${ }^{2}$ Since Port Credit data is amalgamated into the City of Mississauga, the data was found combining the 2 census tracts that represent the location, moreover, 5350504.01 and 5350504.02
} 
Figure 3: The Senior Population (Age 65+ Years) by Peel Neighbourhoods, 2006

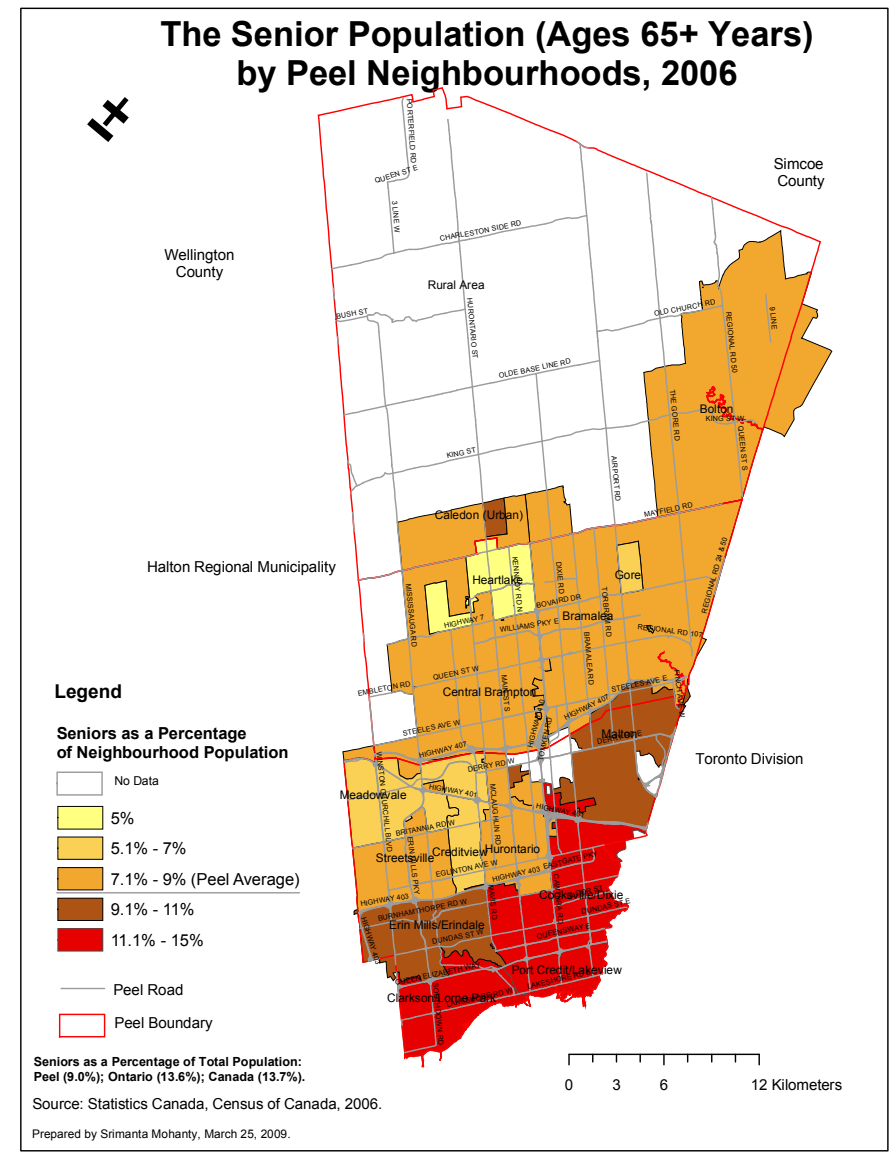

Source: Portrait of Peel, 2012

Furthermore, as seen in table 2 and figure 4, the age population for the Region of Peel is projected to undergo a noticeable increase in its senior population and a visible decrease in its younger population (Ontario Ministry of Finance, 2012; Peel Advisory Working Group on Older Adults' Housing, 2004). Not only will more of the population of seniors be increasing over the next few decades, but it was also found that $74 \%$ of seniors in the City of Mississauga do not plan on moving away from the City within the next 10 years (City of Mississauga, 2008). The city has put in place some initiatives to address the unprecedented growth in the seniors 
population, and lessons learned from this municipality may be helpful to other municipalities in the GTA.

Table 2: Population Projections for the Region of Peel, 2011-2036

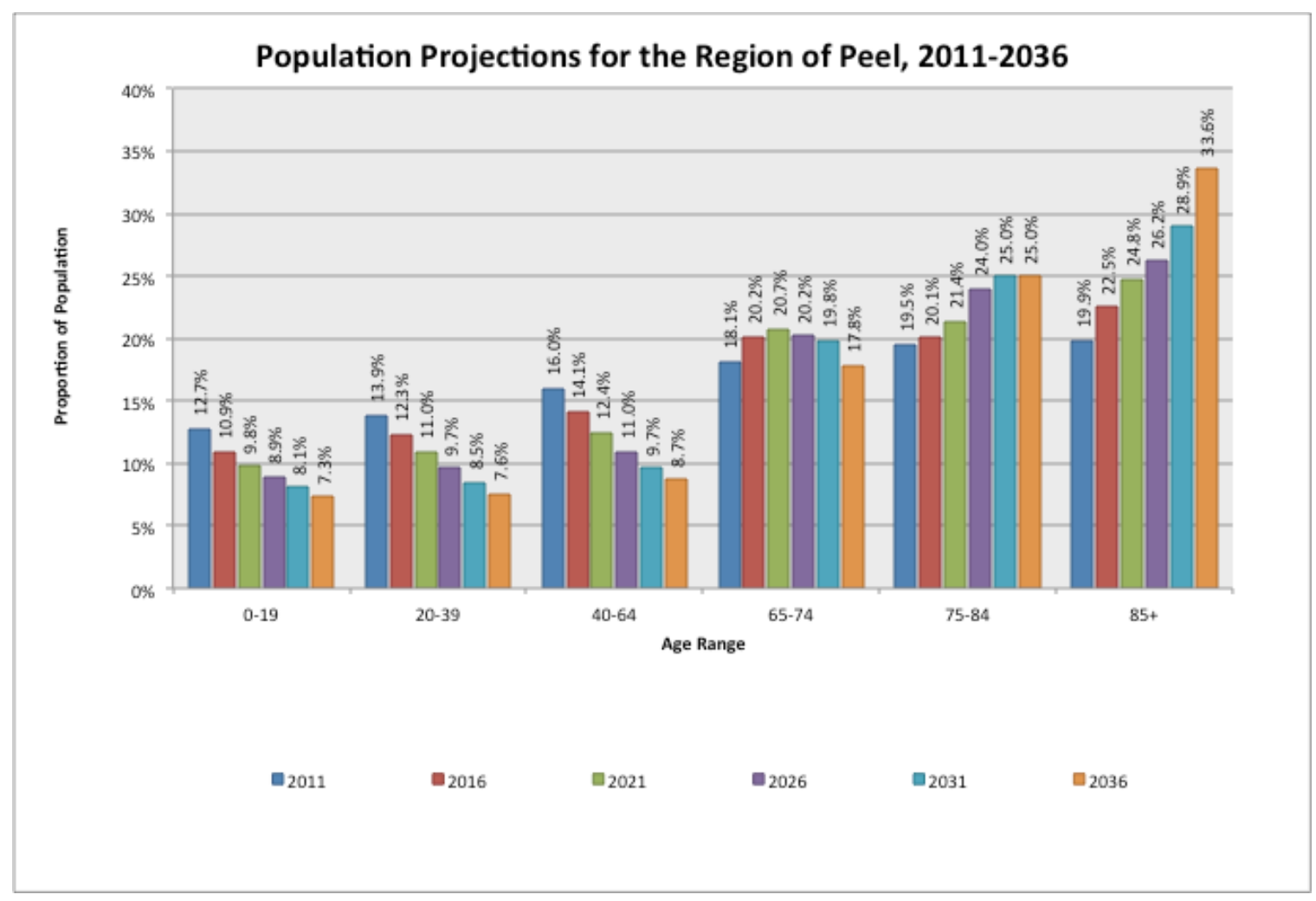

Source: Ontario Ministry of Finance (2012) - Calculation performed by Levine, B.

Figure 4: Peel's Population Distribution of Adults 55 Years or Older

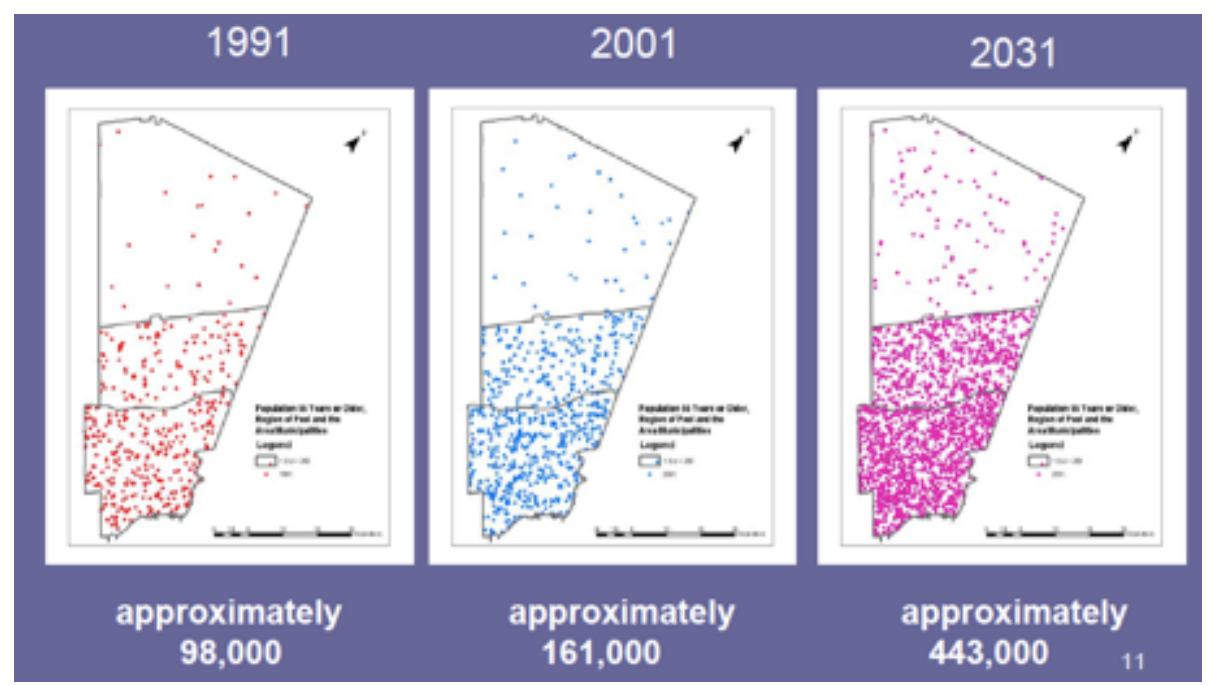

Source: Peel Advisory Working Groupon Older Adult Housing (2004) 


\section{Method and Data Analysis}

The research question for this Major Research Paper asks 'what are the initiatives that the municipality of Mississauga, Ontario is taking towards modifying its current urban built environments to make them senior friendly?' This question will be discussed with regards to housing, transportation and public spaces. The Case Study method, examining the waterfront community of Port Credit was used to complement the review of the literature.

The first method of gathering data was conducting a literature review. This preliminary method was used to review the pertinent data that other authors have used in their research and also discussed the methods that they used to collect the data that they used in their papers. This section highlights the common themes and differences that the various authors have come across in the study of senior friendly communities. There were a few key authors whose work formed the backbone of the research in this section. As stated previously, the WHO (2007) document was used as the focal point for data gathering. The information gained from this document provided a basis for searching for the other literature. Various CMHC documents were also used to gain a better understanding of characteristics of seniors and their changing needs and capabilities. This source was also used for determining information related to seniors and housing. The majority of the information was gleaned from searching online journals. Using the online Ryerson Library search engine provided access to several databases related to urban planning such as ProQuest Research Library, Sage Journals Online and Academic Search Premiere. Furthermore, by having access to a distinguished professional on the topic of seniors' housing, Dr. Christian Fisker, he was able to provide access to key documents that otherwise might have been difficult to come across. The review and analysis of data from these sources 
provided an insight into what other municipalities have incorporated to make their urban built environments more accommodating to seniors and thus provide a benchmark for the discussion on the town of Port Credit.

The second method of gathering data was the case study method. As previously stated, the Port Credit neighbourhood will act as the location of study. This portion of the paper firstly provides a description of the area and its history. The data for this section came primarily from community profiles, official plans, CMHC reports and Statistics Canada resources. The bulk of this section examines what has been planned in order to modify the urban built environment to improve the quality of life of seniors. By analyzing reports, plans and other government documents, in addition to primary site visit observations, the information provides an illustration of what has been done thus far in regards to the research question.

This method also involved gathering information through key informant interviews. This was the method that proved the most time consuming, as it required contacting individuals directly, which was often a challenge. This avenue was crucial as it played a guiding role in prescribing recommendations at the end of the report. The individuals interviewed for additional information are planners for the City and a residential developer who has completed residential developments in the area. These individuals had more detailed and specialized knowledge of the neighbourhood and could better measure the importance of senior friendly initiatives compared to other more pressing issues in the area. 
The challenges for this method were narrowing the scope of study and organizing the key informant interviews. Since there are an abundance of sub topics with regards to senior friendly cities, the scope had to be narrowed in order to keep the research paper in focus. As such, only housing transportation and public spaces were studied. Also challenging was the scheduling and logistics of interviewing key informants due to distance and time restraint factors. To mitigate these challenges, these individuals were contacted as soon as possible in hopes to avoid any last minute rushes or any other avoidable setbacks. They were also sent reminders by emails and were contacted over the phone to confirm their availability. Moreover, by preparing a list of questions as early as possible, it allowed a greater deal of preparation, which made the interviews themselves run much more smoothly. 


\section{Literature Review}

The literature is structured in a way that attempts to clearly identify the key themes that will be discussed throughout the paper. This section begins with an overview of the demographics and then diverges into the three main areas of interest for the research question. The first topic covered is housing, the second topic transportation and lastly, public space.

\section{Demographics}

It is widely recognized that there is a significant change in demographic trends on the horizon. On a global scale, the segment of the population 60 years and older will double, from $11 \%$ to $22 \%$, in proportion by the year 2050 from what it was in 2006 (Plouffe \& Kalache, 2010). At a more local level, it is estimated that the Canadian population 55 and older will increase from $25.3 \%$ in 2006 to $35.1 \%$ in 2036 (CMHC, 2012). These statistics suggest that the Canadian population 55 and older will increase by $48 \%$ during that 25 year time period.

\section{Housing and Access to Services That Address Seniors' Needs}

As the baby boomers, those born between the years of 1946 and 1964, age into their later years of life, it will undoubtedly have consequences in terms of how cities will be reshaped (Holeywell, 2012; CMHC, 2008) and will have implications on services delivered by cities (Hemson Consulting Ltd., 2003). This consideration for a need of increased and more importantly, more specialized services in close proximity to where seniors live, is one of the key findings from a presentation by Raymond Applebaum, the chair of Peel Advisory Working Group on Older Adults' Housing in 2004 (The Peel Advisory Working Group on Older Adults' Housing). He explained that through a mixed method of surveying 6,000 seniors (with a $22 \%$ 
response rate) and eight focus groups with a total of just under 100 participants, which was considered to be "one of the most comprehensive research projects in Ontario that examine[d] housing needs of older adults" (2004, slide. 19), that one of the most important factors of housing for seniors was the presence and proximity to doctors and hospitals (City of Mississauga, 2007). Furthermore, other necessary and nearby services that seniors see as being central to their daily lives and closely linked to their independence include, grocery stores, drug stores, the bank, restaurants, post office, church or other religious institutions, seniors' center and the library. A significant point to address is that according to Hodge (2008), these destinations are usually located within two to two-and-a-half kilometers from where they reside and even up to ten times more in a rural context. The location of and distance between housing and amenities is seen as a barrier to seniors with limited mobility and a lack of easy accessibility or are no longer able to drive (Hodge, 2008). Germane to discussing their future needs in relation to housing, for seniors, is city design and the impacts of urban sprawl.

Historically, over the past century, regulations, land use policies and zoning have tried to address the ills resulting from urban living. The resulting regulations have had significant impacts on North American city design and resulted in a built form that favours families with young children, with an automobile, isolated from commercial uses and are thus "poorly suited to the needs and capacities of their aging inhabitants" (Scharlach, 2009, p. 8). These changes in needs and capabilities are often the consequences of injury, disease or aging in general. It is important to note however, that strictly using age as an indicator, is a weak predictor of seniors' needs and capabilities according to Hodge (2008), a prominent figure in the field of planning for the aging population. To be more specific, approximately $25 \%$ of Canadian seniors have 
difficulty with one or more activities including hearing, seeing, communicating, walking, climbing stairs, bending, learning or other similar activities (Statistics Canada, 2006). In addition to this problem is the change in abilities of seniors, particularly relating to the issue of housing. The traditional type, moreover, multilevel housing built in a suburban landscape, has been built for a Peter Pan existence, as housing has traditionally been "designed for someone who will never grow old" (2009, p. 5). This belief is echoed by Holeywell (2012) as he asserts that this type of housing stock is out of synchronization with the current market demand and the needs and demands in the years to come. Further research on seniors' related physical limitations suggest that mobility and agility issues have doubled in the percentage of the Canadian population 65-74 years old from 2001-2006 (Human Resources and Skills Canada, 2011). This substantial disconnect, in terms of the physical housing environment, failing to meet the needs and capacities of aging cohort (Scharlach, 2009), has led many to consider alternate and more appropriate approaches to making places more user-friendly to seniors.

More recently, in response to the clear disconnect in city design and its older residents' capabilities, city governments have come to consider more forward thinking approaches to better meet the needs of the senior population. Not only is this a local issue, but meeting such needs is an urgent desire of the province of Ontario as well. In the aim to “...enhance the quality of life for the citizens of Ontario" there is a desire for improving the health of the residents and addressing the need for housing that "meet the social, health and well-being of current, and future residents, including special needs" (the definition of 'special needs' includes seniors) (PPS, 2005, S. 1.4.3.b.1). Concepts such as 'livable communities', 'age-friendly communities' and 'smart growth' can be seen to increase the well-being and independence of seniors. Livable 
communities emphasize among other things, adequate and appropriate housing, community features and services and mobility options that increases independence for all residents (AARP, 2005).

Age friendly cities, according to the WHO, are by definition ones that are inclusive of the senior community by adapting their structures and services so that they become accessible to the aging population, who have a mix of needs and abilities (World Health Organization, 2007). Similarly Smart Growth strategies promote communities that are more compact in size and incorporate mixed-use development which reduces the need for automobile use and encourages alternate modes of transportation for accessing facilities and services (CMHC, 2008; Holeywell, 2012; AARP, 2005,). These strategies provide additional benefit for the entire community and not strictly seniors, as Holeywell suggests "By making the space more accessible for seniors, you're making it more accessible for everyone else" (2012, par. 8). One method in which housing can be made more accessible to people of all ages and abilities is to design them to be easily adaptable in the future.

Plouffe \& Kalache, in conducting semi-structured focus group interviews in the Vancouver area, which were used in gathering data for the World Health Organization's Global Age Friendly Cities Guide, aimed at identifying preferred features for an age friendly housing and community. One feature that was highlighted was the need for appropriate design of any newly built environment and suggested that it should be designed in a way to anticipate users with different capabilities, thus friendly to seniors and also people of all ages (2010). As stated previously, the method used to produce the World Health Organization guide itself was 
comprised of data collected through focus groups from thirty-three cities around the world. The guide specifies eight areas crucial in studying age friendly cities.

The $2008 \mathrm{CMHC}$ report, discussing the impacts of the aging Canadian population on housing and communities, found a similar result, among others, using the literature review method. The report found that seniors have a preference to 'age-in-place' and stay in their homes for as long as possible, rather than move out prematurely. The desire to 'age-in-place' suggests that there would be a need for adapting the home environment as the abilities of the senior changes over time. On a general level, the ability to age-in-place and remain in one's own home environment represents a sense of security as it holds memories and may be more likely to be in close proximity with friends and family (Hodge, 2008). Scharlach (2009) too brings up the importance of place attachment, and that people give significant meaning to the place where they live and thus offers the notion that staying in one's own place of residence rather than moving, is the ideal option for seniors. However, seeing as how many individuals in their old age may not be able to attend to or even have the technical know-how to take on lofty home modification projects themselves, there is a suggestion for the need of home maintenance and support services to be available in the community (CMHC, 2008; Hodge, 2008). The report recommends that in order to facilitate this, building code regulations should be adapted to allow for new forms of building design (CHMC, 2008). This recommendation has also been echoed in the province of Alberta, as the 'Greater Edmonton Alliance', a non-profit group, seniors' care team, concluded at a meeting in October 2012, that solutions to better seniors housing design can be achieved through "Changes to the Alberta Building Code to allow for more senior's friendly housing" (GEA, 2012, par. 13). This type of intervention could perhaps include looking into the 
experience of other countries where "a wider range of disciplines have been more substantially involved in reviewing changes to building codes" (Edwards \& Speer, 2010, p. 5)

Scharlach (2009) too recognizes the importance of home modification, as he notes that $14 \%$ of homes occupied by seniors in the US were in need of repair in 2004. This type of home improvement project could be a financial burden on some senior homeowners. The Province of Ontario has realized this, and offers credits to seniors who take on such projects. Through the Healthy Homes Renovation Tax Credit, seniors are able to claim up to $\$ 10,000$ worth of home improvement costs on their tax returns and such expenses are refunded at rate of $15 \%$, ending up with a refund of up to $\$ 1,500$ (Province of Ontario, 2012). This would in effect give seniors the opportunity to remain in the environment that they have become accustomed to and not have to move to a new and different area when their current home is no longer suited to their needs and capabilities.

An additional strategy addressing this issue of home adaptability can be seen in 'Flex Housing'. The CMHC (2006) defines this type of housing as "Homes which can be easily adapted to meet future needs/lifestyle" (slide. 2). The presentation highlights this type of housing as focusing on three A's, these being, accessibility, adaptability and affordability. The accessibility factors address items dealing with simple issues, such as on-grade entries for doors, accessible outlets and switches and the maneuvering of interior space. These subjects of concern, although seemingly insignificant, are critical for independent living for seniors as their diminishing abilities may not allow them to function seamlessly in a unit with traditional design features. 
Flex-Housing suggests that the housing unit should be made to be readily adaptable. One such example is to have the unit layouts compatible for the conversion of a two-storey home into a duplex or even to allow the conversion of an attic into additional living space, both of which allow the senior to remain at home and have additional users (friends, family, live in help) in which to live and share the space. The last feature of 'Flex-Housing' to note is that it should be affordable. The CMHC document explains how retrofitting units to be more accessible has only a minimal upcharge and incorporating adaptable features can offset costs by receiving additional revenue in terms of secondary suites. As for affordability, it has been calculated that the cost increment of building a two-storey, 1746 square feet in Ottawa would only be an additional $5.5 \%$, or $\$ 150,905$ compared to a non Flex-Housing unit at $\$ 143,072$ (CMHC, 2006).

However, as found in other reports on the topic of housing affordability, often times the cost of using certain desired materials or construction techniques could outweigh the potential benefits. The author points to findings in the Australian Housing and Urban Research Institute study from 2008 and suggests that policy geared to the provision of home maintenance and modification services is a necessary provision in a healthy community for seniors. A report by the American Association for Retired Persons (AARP) on public policy utilizes the literature review, mostly of housing surveys, though original survey research was also incorporated and discusses similar issues. The report discusses housing with regards to age-friendly communities and included home design, housing type, modifications, affordability and how they all relate to changes in needs as seniors age, noting once again the desire of many seniors to age-in-place (2005). 
Key informants are also used in the literature so as to gain more detailed information, as this serves as direct access to specialized information to complement basic literature reviews. Holeywell (2012) uses a combination of the aforementioned methods. He employs information that was garnered from speaking with architects, county officials, and authors who have written on the subject, to add to the information found when examining Arlington, Virginia as a case study. These stakeholders help in understanding the changes that cities are starting to employ to make their environments friendly to seniors. Though there is a focus on transportation and public space initiatives, housing is also discussed. The author looks at how newly developed zoning ordinances were added to accommodate secondary suites, thus permitting seniors to live closer to relatives or friends. Moreover, building design, as previously discussed by Plouffe \& Kalache (2010) and CMHC (2008), was a notable point. Wider hallways allow greater access for individuals dependent on wheelchairs and by pre-installing infrastructure to allow for cheaper and easier installation of items such as grab bars for washrooms, it returns back to the theme of designing with the anticipation of changing abilities and needs of seniors (2012). The preference of housing types for seniors in the Peel Region was also found to be of interest.

Results from the 2004 study done by the Peel Advisory Working Group on Older Adults' Housing, also indicates that the preferred dwelling of seniors in the Peel region is single level living spaces. Hodge (2008) also discusses the preference of seniors in some cases to downsize and when appropriate, move into a smaller and more manageable living space. The final results from the Peel Advisory group display that the most desired building type is the single detached dwelling (44\%) followed by low-rise apartment (19\%), high-rise apartment (12\%), row house/ 
townhouse (8\%) and semi-detached (3\%). The next section will transition away from the issue of housing and will explore the topic of senior friendly neighbourhoods with a lens focused on transportation.

In summary, an age friendly neighbourhood is one that allows for seniors to live in close proximity to key amenities and health services. The type of housing, in terms of physical design, should also reflect the changing needs and capabilities of a senior citizen and recognize that the conventional suburban house can be ill suited to senior accessibility. Neighbourhood design should promote Smart Growth strategies can provide an increase sense of independence and allow for seniors to get around without the need of a private automobile. This is all to say that senior friendly neighbourhoods allow seniors to age-in-place. Home modification and adaptability are key issues that can allow seniors to remain in their home and communities. By having a more adaptable and flexible the housing environment, seniors can continue to live independently without the need to seek alternative housing options.

\section{Transportation}

The changing needs and capabilities outlined above also have an impact on seniors in terms of transportation. Rosenbloom discusses in her review of the literature how "an aging society adds to a range of transportation problems..." $(2003$, p. 1$)$. It is found throughout the literature that seniors, especially women, live alone as they may have never married, divorced or widowed (Rosenbloom, 2003) and thus are more likely to be isolated. Moreover, seniors are found to be reliant on the private automobile and when they can no longer drive or must give up their license, they become less independent, free and thus isolated as a result (Stromberg, 2007; 
Fisker, 2012). This notion is supported from a survey from 2004 by Transportation Policy and AARP, whereby it was found that half of seniors that do not drive, stay home because they lack convenient transportation options. There is a negative financial consequence on the local economy as well, as there is a reduction in buying power of the less mobile senior population (Stromberg, 2007).

The discussion on seniors and automobile use is more suited for a suburban context, whereby it is found that seniors in urban environments are much less likely to drive compared to their suburban counterparts (Rosenbloom, 2003). Seeing as seniors in Canada are driving less and less due to age-related changes in vision, reaction time, power, coordination and the speed of cognitive processing, hearing and agility due to arthritis or rheumatism (Canadian Medical Association, 2006 in Public Health Agency of Canada, 2010; Hodge, 2008), public transportation availability is a key issue in senior friendly environments. The WHO guide suggests that having a range of transportation services is necessary for meeting the range of needs of seniors (2007). Further more, it is suggested that the most significant aspect of public transportation according to seniors is accessibility (Hodge, 2008).

Having a reliable and accessible public transportation system can allow seniors to regain a sense of independence that may be taken away once they no longer can rely on the private automobile. This is reaffirmed in the document put out by the United Nations Centre for Human Settlements (UNCHS) where it states, "inaccessible transport continues to be a tremendous barrier to independent living, because it restricts the choices for housing..." (1993, p. 34) as it limits the areas where seniors can chose to live. Stromberg (2007) and Rosenbloom (2003) also, 
stress the importance of the availability of public transportation for seniors and also suggest having specialized services such as door-to-door services run on a voluntary basis to compliment and fill the gap of what the city is not providing. Reliable public transportation service is also another component of age-friendly communities as discussed earlier in the text (WHO, 2007). Rosenbloom (2003) also makes such a recommendation when she suggests that seniors would consider making better use of public transportation if the service was provided to better meet their needs and notes that improving conventional service, among others aspects, could address this issue. Hodge (2008) also stresses the availability of transportation for seniors and looks at the physical environments in terms of the terrain, presence of complete sidewalk systems and the distance between transit stops, as significant factors of independence in terms of transportation. These criteria also play a role in the walkability of cities. Mixed-use neighbourhoods with high connectivity and high residential and retail density play a significant role in increasing an area's 'walkability' (City of Toronto, 2012). It has been shown that walking can provide many health benefits to seniors due to the increased levels of exercise, such as lowered risk of chronic disease and improved immune system. However the physical environment that the senior lives in, may in fact, discourage them from walking and obtaining such benefits. Barriers to walkability include the distance between origins and destinations, the absence of crosswalks, sidewalks and other pedestrian amenities such as benches. In addition, the time allotted to cross at a crosswalk had also been shown to be too short for many seniors to make it across the street (Traffic Safety Center, 2002). The lack of weather protective features, such as awnings or bus shelters, are also an aspect of the public realm that can affect walkability, as it provides shelter from the elements such as rain, snow and sun and wind (Ziebarth, Erm \& Hwang, 2010). The next section will 
transition away from the issue of transportation and will discuss the topic of senior friendly neighbourhoods with a lens focused on public space.

In summary, public transportation and active transportation are both critical issues as seniors lose the ability to drive their own private automobile. Of greater importance is the accessibility of these alternative forms of transport. A poor public transportation system and active transportation network can have a negative impact on seniors' independence and overall physical health.

\section{Public Space}

Public spaces, such as sidewalks, parks and plazas, are tremendously important for seniors. These spaces are vital as they provide space for seniors to congregate and socialize together. The ability to easily navigate these spaces is also critical for seniors' independence (Efroysmon, Thanh Ha \& Thu Ha, 2009). The WHO (2007) guide highlights public spaces (which is referred to in the WHO guide as including outdoor space and buildings) as a significant aspect of age-friendly cities. The guide outlines several specific areas within the public space realm that should be addressed (environment, green space and walkways, outdoor seating, pavement and roads).

The WHO guide (2007) recommends that an age-friendly city should have ample seating available for seniors to use to rest, highlighting particular areas of focus such as in parks and at transport stops. An example from Sweden is used by the UNCHS (1993) document where it 
highlights an initiative that makes their pedestrian networks more senior friendly by adding additional signage indicating the presences of walkways and also punctuating these networks with rest area benches. It was noted by Hodge (2008) that the activity of simply going out for a walk was an activity often enjoyed by seniors. Therefore, having trails and paths accessible for seniors of all capabilities is crucial for the senior friendly public space.

By making it easier for seniors to navigate the public realm, it can be argued that it can ameliorate their spirit. The WHO (2007) guide further suggests that walkways throughout the city should be free from obstructions have smooth surfaces and be at an appropriate height to allow for a curb to taper onto the road, thus providing more accessibility for all pedestrians, regardless of physical ability. These suggestions also tie into the issue of active transportation and walkability, as noted in the previous section, thus highlighting the crossover and importance of this issue in senior friendly neighbourhoods.

There should also be consideration for the indoor environment where the issue of stairs must be addressed as seniors account for more than half of all wheel-chair bound persons in Canada, who take part in activities outside their home (Moore \& Pacey, 2004 in Hodge, 2008) The outdoor environment is just as important to address. An example of an improved outdoor environment is reiterated in the UNCHS report where an example from Tokyo Japan illustrates how its curb cut program aims at improving the conditions for wheelchair-bound and visually impaired pedestrians. In this example the use of textured surfaces is used to indicate changes in level and direction of pedestrian crossings. Moreover, the use of lights and sound in addition to 
providing an extra twenty seconds for the elderly or individuals with disabilities to cross an intersection are used as making environments more age-friendly (1993).

The WHO (2007) guide further recommends having adequate green space as a feature of age-friendly cities. The document notes that in some cities, green space is either poorly maintained, does not have protection from the elements or is too crowded. There is an emphasis throughout the guide to have clean public spaces that would be appealing to seniors and allow them to use this public space. The UNCHS (1993) report also discusses the importance of clean green space. The WHO guide states that "(h)aving green spaces is one of the most commonly mentioned age-friendly features" $(2007$, p. 13). It is also recommended that these green spaces be accessible and safe (UNCHS, 1993). The document briefly describes an initiative in France where a pensioners' association helps in maintaining flowers and greenery while receiving compensation for their work. Moreover is the importance of the availability and accessibility of public washrooms for seniors and the disabled. Public toilets, according to the WHO guide, are seen as one of the essential age-friendly features of the built environment (2007). The WHO (2007) and UNCHS (1993) both advocate for strategic positioning of these necessities throughout the city, highlighting areas of high levels of public activity such as intersections, parks and city squares. Further, is the necessity of stalls wide enough for wheelchairs and also the presence of grab bars in public washrooms.

In summary, several features of public spaces can greatly influence the success of public space in senior friendly neighbourhoods. The literature suggests having ample seating, appropriate signage and the availability of trails as a few notable features. Moreover, it is of even 
greater importance that these features, in addition to public washrooms, be accessible, well maintained and safe. 


\section{Results and Discussion}

\section{The Case Study Setting}

The results for this section have been collected through a case study of Port Credit Village and its surrounding areas, first hand data collection through site visits, key informant interviews and through reviewing pertinent policy documents for the City of Mississauga and Port Credit specifically. These documents include the Mississauga Master Plan, the Port Credit Local Area Plan (Draft), the City of Mississauga Strategic Plan and Action Plan, the City of Mississauga Older Adult Plan, the City of Mississauga Accessibility Design Handbook and other City documents.

\section{Recent Developments}

Port Credit is experiencing a wave of mixed-use intensification. One recent example is the Port Credit Village development. Located at the corner of Hurontonian Street and Lakeshore Road East (see $5 \& 6$ ), it is seen an ideal example of a senior friendly environment in terms of housing, transportation and public space.

Figure 5: Port Credit Village Transportation Map

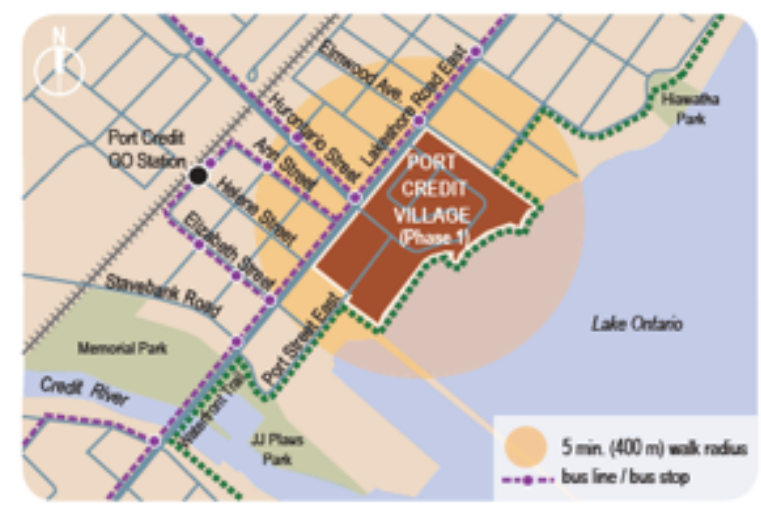

Source: Ontario Ministry of Energy and Infrastructure (2009) 
Developed in 2005, this Transit Oriented Development (TOD) neighbourhood (CMHC, 2007) is a twenty-six acre mixed-use development, made up of 225 condominium apartments, 167 townhouses and eighteen live-work townhouses with an average height of three stories. Developed by FRAM Building Group, it also provided $1,400 \mathrm{~m}^{2}$ of office space and $3,700 \mathrm{~m}^{2}$ of mixed-retail in the area. The development is located in close proximity to a GO Transit station, in addition to the local commuting services. As was mentioned previously, one of the goals of smart growth and other senior friendly communities is to have a dense and compact urban form, allowing for people to walk to destinations and/or use public transit alternatives and not have to rely on the private automobile. It was noted "The number of riders who walk to the Port Credit Station is one of the highest for all GO stations" (CMHC, 2007, p. 3), thus demonstrating the effectiveness of such an urban built environment on being accessible in terms of walkability. These types of developments do not happen haphazardly, but rather are the result of a combination of local and provincial policy that encourages such smart growth initiatives

Figure 6: Port Credit Village Master Plan (Phase 1)

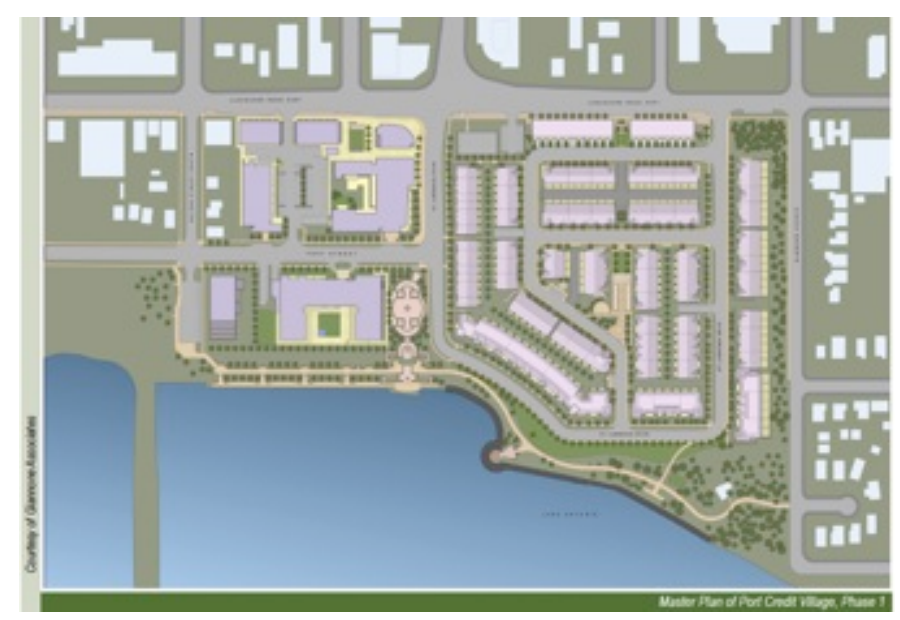

Source: CMHC (2007) 
The desire for a strong and complete community is addressed by policy in the Mississauga Official Plan, more specifically, in the Port Credit Local Area Plan, 2012. This is clearly an attempt to comply with the Provincial Policy Statement, 2005 and Growth Plan for the Greater Golden Horseshoe, 2006 (pertinent policies can be seen through figure 7, which promote and emphasize the importance of intensification, transit supportive densities and an urban form that is supportive of walking and demonstrate Port Credit as a node.

Figure 7: Relevant Growth Plan Policies

Policy 2.2.3.7 (b, c, d, e, f): Plan and design intensification areas to provide a diverse mix of land uses to support vibrant neighbourhoods; provide high quality public open spaces with urban design standards that create attractive and vibrant places; support transit, walking and cycling; and achieve higher densities than the surrounding area, with an appropriate transition of built form to adjacent areas.

Policies 2.2.5.1 and .2: Plan major transit station areas to achieve increased and transit-supportive densities; mixed residential, commercial, and employment uses; access to transit facilities from a range of transportation modes; and accommodation of local services, including recreational, cultural, and entertainment uses.

Policy 2.2.7* a, b, c, d: Plan and design designated greenfield areas to contribute to complete communities; create street configurations and densities and urban form that support walking, cycling, and transit; provide a diverse mix of land uses to support vibrant neighbourhoods; and create high quality open space with urban design standards that support transit, walking, and cycling.

Source: Ontario Ministry of Energy and Infrastructure (2009)

Section 8.0 of the Local Area Plan addresses this striving for strong and complete communities. This section describes how Port Credit is and should maintain a "compact urban form that is walkable, provides convenient access to a mixture of land uses and assortment of activities such as: shops, community facilities, parks and public transit" (Port Credit Local Area 
Plan, 2012, p. 12). The urban built environment is also changing in terms of densities and changing physical shape, form and location of new housing.

\section{Housing and Access to Services That Address Seniors' Needs}

Port Credit's history is that of a predominantly single family district (CMHC, 2007). Introducing higher density, especially in close proximity to a mass transit station, is clearly an attempt at modifying the built urban form. Due to the neighbourhood's connection in the surrounding grid pattern street system, the area has been the focus of intensification since as early as the 1950s (Ministry of Energy and Infrastructure, 2009). This desire to continue intensification and modify the urban built form is addressed in the Local Area Plan in section 9.3 under the heading 'mobility hub', where it emphasizes a greater concentration of housing and other uses in the vicinity of a transit station. The type and form of housing, as well, represented a shift in the traditional housing options in the area. As previously stated, the area has previously been characterized by single-family dwellings.

Port Credit village however represents a shift to a much more densely built form, as $56 \%$ of the dwellings are considered 'multi family' (CMHC, 2007) and symbolizes a shift from low to medium density development in the area. Thus the urban built form of senior friendly neighbourhoods is characterized by a more dense urban form and is consistent with the characteristics of a senior friendly neighbourhood as described in literature review section. Port Credit village differs from the conventional built form in that it shifts away from low-density single detached dwellings, and instead provides options with greater densities such as townhomes and mid-rise apartment buildings. Moreover, the presence of live-work units, 
although just a small portion of units built, suggests that this type of housing unit can accommodate residents through their various stages of life. This issue should not be underplayed, seeing as it is found that many seniors will have to work past the age of sixty-five years old (City of Mississauga, 2008) either part time or full time.

Moreover, the literature suggests that this age cohort is more likely to be self-employed and more likely to work in business services (MacEwen, 2012). A key informant interview (personal communication, March $15^{\text {th }} 2013$ ) noted that these units are typically smaller in size and occupied by younger business oriented residents. This being the case however should not retract from the type of changes that are taking place, as it highlights the reduction in long distance commuting and overall walkability of the area.

It was also confirmed through the key informant interview that the design and layouts of the units being provided in both market housing section of Port Credit Village development and Port Credit Residences are substantially larger in size than those offered in areas such as downtown Mississauga or Toronto. Though this differs from Hodge's (2008) viewpoint that seniors will tend to downsize, it was discussed that larger units can better provide wider hallways to not prohibit the use of wheelchairs or walkers. Moreover, specifically to the retirement residences, the units benefitted from customization in terms of washrooms that were specially designed for individuals with limited mobility such as through wheel in showers. This type of interior design strategy can benefit seniors in terms of increased safety, as it can prove to reduce the risk of personal injuries, such as slipping and falling over (key informant, personal communication, March $\left.15^{\text {th }} 2013\right)$. 
It is also worth noting, that the strategic location of Port Credit Residences is located less than 3 kilometers away from the Mississauga Trillium Health Centre, the local hospital, and can be reached by car in less than 10 minutes and under fifteen minutes by bus (Googlemaps, 2013). Moreover, there are several health related services located within walking distance of the residences. These include a dentist, chiropractor and a pharmacy, just to name a few. This is consistent with the literature that suggests that proximity to a hospital is a vital concern to seniors in terms of location of housing (City of Mississauga, 2007). Though many of these establishments were present prior to the development of Port Credit Village (key informant, personal communication, march 15 2013), it is meant to demonstrate the senior friendly communities of the future should offer immediate access and proximity to medical services, since as seniors age, they will require more and more personal care. The compact urban form, in combination with the presence of desired amenities, further suggests that Port Credit is an area that can cater to seniors throughout different phases of their later years in life. It provides an ideal place to age-in-place.

As discussed earlier in the text, aging in place is seen as one of the better options for accommodating seniors. Action 9, in the Mississauga Strategic Plan titled, 'Enable older adults to age-in-place' explains how the City, in conjunction with the Region, aims at developing a strategy that will enable seniors to age in their current residence or immediate area for as long as possible (2009). It is also noted that moving into a different unit, especially in a different part of town can be costly, stressful and have negative impacts on their physical well being as found in the City’s Older Adult Plan (City of Mississauga, 2008). One strategy that is currently being 
explored is found under Action 7, 'Legalize accessory units', as they are currently permitted in the City's Official plan but not in the City's zoning By-law (City of Mississauga, 2013). Again, secondary units, or secondary suites, are "self-contained living units in dwellings..." (City of Mississauga, 2013). This policy objective will bring physical changes in the built form of housing in terms of the appearance of either additional structure on a property or a secondary suite within an existing structure. This strategy can benefit seniors in making their housing options more affordable, as this option is a component of the 'Housing Choices: Mississauga's Affordable Housing Strategy' (City of Mississauga, 2013). This assumption is further accepted and supported in the Housing Choices: Second Unit Review (City of Mississauga, 2012), as in section 3.3.1, as it states through public consultations, seniors were identified as a group of the population who can benefit from the legalization of secondary suites. As of February $25^{\text {th }} 2013$, there is currently a proposed zoning by-law, 022-2007 Amendment for Second Units (City of Mississauga, 2013). While still discussing aging-in-place, it should be noted that, at least in the new FRAM development, the newly built units were not built to be flexible or adaptable, thus unable to change according to the changing needs and capabilities of seniors (key informant, personal communication, March 15, 2013).

It was learned through an informant interview (personal communication, March 15, 2013), that there are seniors currently living in Port Credit Residences who lived in Port Credit for most of their lives, then moved into the Residence when they were no longer able to live independently. This is an example of aging-in-place as it demonstrates how a senior can remain within their community and not have to seek accommodations in an unfamiliar environment 
where they might not be nearby to family and friends and services such as doctors and hair salons.

One issue worth addressing is that due to Port Credit Village and Residences' scenic waterfront location, the affordability of housing can pose an issue for seniors with limited income. This particular development is catered to a clientele, with the financial means to afford to live in such a desirable location. Although this might be true for the waterfront community specifically, it is noted in the City's Official Plan, under section 7.0 Complete Communities, that for the past thirty years, people have been choosing to relocate to Mississauga due to its affordable housing prices (City of Mississauga, 2011, 7-1).

\section{Transportation}

The Action Plan for the City of Mississauga's Strategic Plan's Action Plan (2009) paints a picture where the future residents of the Municipality can get around the city without an automobile and promotes the use of transit and other healthy lifestyle options of transportation. As touched on in the literature review section, it is suggested by Hodge (2008) that transit stops in close proximity to where seniors reside, is crucial for their independence if they no longer have the ability to drive a private automobile.

The section titled 'Belong' within the Action Plan, provides several 'actions' that aim to benefit seniors, which have direct impacts on urban built form and transportation services, the most significant of which is Action 2: Designates older adult clusters in mixed-use areas. This policy objective is clearly looking to modify the urban built form to make parts of the 
neighbourhood friendlier to seniors. This section describes how new retirement centers and seniors' apartments should be built in nodes and corridors that have direct access to a wide range of services, programs, amenities and especially transit (City of Mississauga, 2009). This can be seen to be consistent with the literature whereby senior friendly communities should be designed to be walkable and provide access to amenities and thus reducing any type of isolation or lack of independence associated with traditional suburban neighbourhood design. It can be argued that this desired senior friendly form of development is currently being fulfilled in Port Credit. An example can be seen through the seniors' housing project in Port Credit Village, namely, Port Credit Residences, located at 33 Hurontonian Street, one street south of Park Street East. This seniors' housing project is strategically located in close proximity to Lakeshore Road, a main street providing sought-after amenities such as grocery stores, cafes, and a health and wellness center. Moreover, it provides seniors who are no longer able to drive with immediate access to the GO Train station and transfer stops for the local MiWay bus service. This type of project seems to fit the goal vision stated in the Local Area Plan, which also advances the goals of the Strategic Plan in "directing growth to support transit" (City of Mississauga, 2012, p. 14).

Furthermore, looking into the future, the Action Plan sets out actions such as 'providing alternatives to the automobile along major corridors' and 'create mobility hubs', which together recommend investments in transit infrastructure (LRT/ BRT/ Transit Priority) in areas with practical densities. As discussed in the locational context, the senior population alone is expected to increase dramatically (see tables 2 and 4 ) over the next few decades. So far, with the TOD development of Port Credit Village (Port Credit Residences), it is seen that efforts are well underway in developing the urban form in conjunction with the transportation network. During a 
key informant interview (personal communication, March $15^{\text {th }}$ 2013) it was supported that Port Credit Village, is in fact as walkable as advertised. At many points in the interview session, the informant noted how the majority of the residents of both the market homes and retirement residences are living in an urban environment where the use of the automobile is not required, and often not used regularly. The informant continued and explained that if seniors need to commute to area such as downtown Toronto for work or entertainment, the proximity to the Port Credit GO Station allows them to access those areas without the need of a car.

Under section 9.1 Multi-Modal Network, the Local Area Plan suggests that the road and transportation network should consider the needs of all users within the community and from outside (City of Mississauga, 2012). One example of the type of initiative that benefits seniors throughout Port Credit can be seen in the crosswalk network at major intersections. As seen in 87, the crosswalk signage is quite large and clear, making it easy to see and read so that individuals with reduced eye-sight capabilities are given a better opportunity to operate the crosswalk device.

Figure 8: Crosswalk signage 


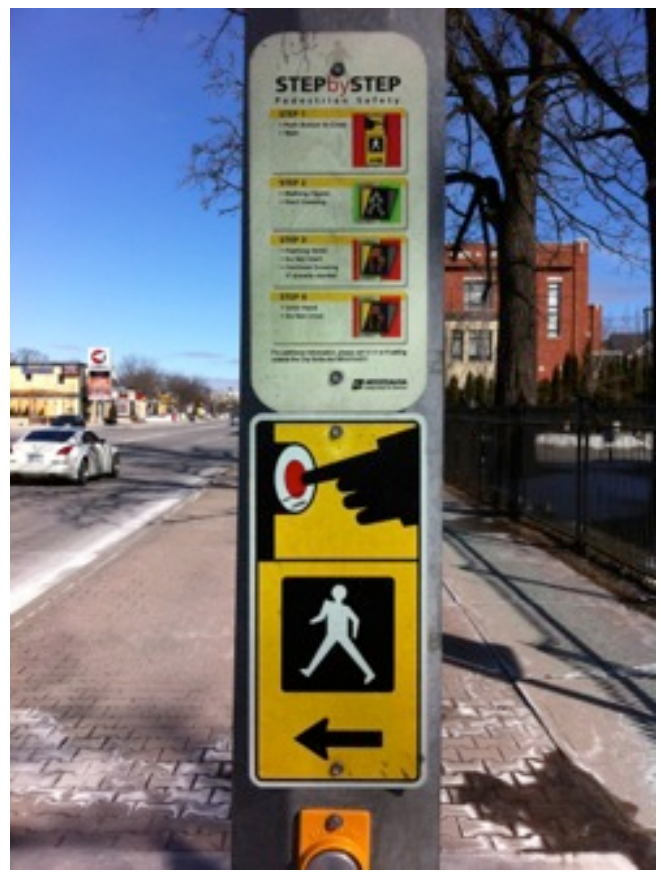

Source: Levine, 2013

\section{Public Space}

The Port Credit Village and Residence provides the type of public realm that is currently friendly to seniors in many ways. As was mentioned in the literature review, by the WHO (2007), age friendly cities should provide benches at strategic points scattered throughout the public realm available for seniors, as some seniors with physical limitation often require places to rest in between their travel from origin to destination. The City of Mississauga has addressed this issue in its Accessibility Design Handbook. Section 2.5.5 Benches and Street Furniture clearly outlines the City's desire to accommodate those who need adequate places to sit and rest throughout the public realm. The section begins with the statement "Benches and other street furniture... should be designed and positioned to maximize safety and utility for all users. For instance, benches installed along barrier-free routes, at entrances and waiting areas, offer a place 
to rest, which is especially important for the comfort of people with a disability and seniors." (2007, p. 2-35). Not only is this simply a suggestion, but also it was revealed through site visits that there is in fact a good amount of seating, especially in Port Credit Village. Seating areas can be found along Lakeshore Roads East at transit stop terminals (see 98) and along the Waterfront Trails (See figure 10) and in park space (See figure 11).

Figure 9: Seating space at a bus shelter on Lakeshore Road East

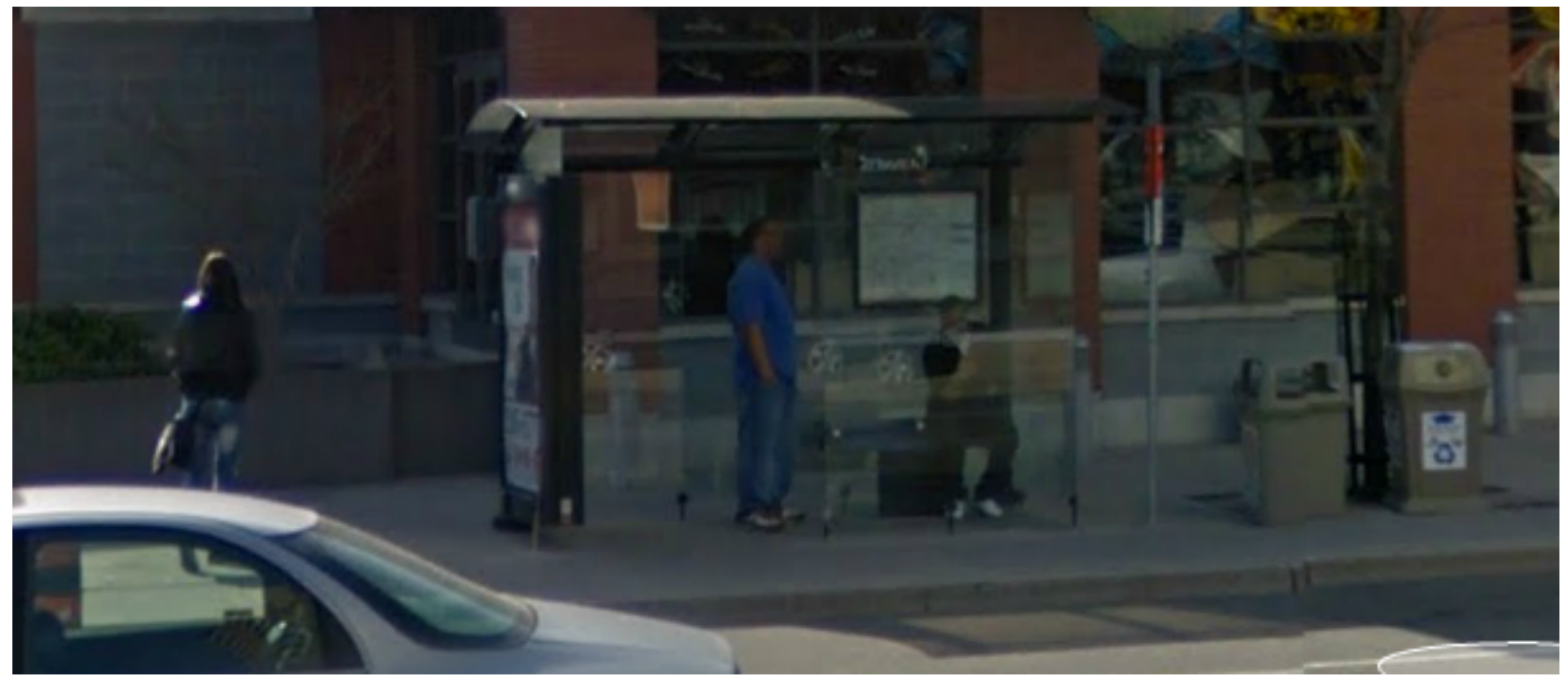

Source: GoogleMaps (2013)

Figure 10: Benches on the Waterfront Trail

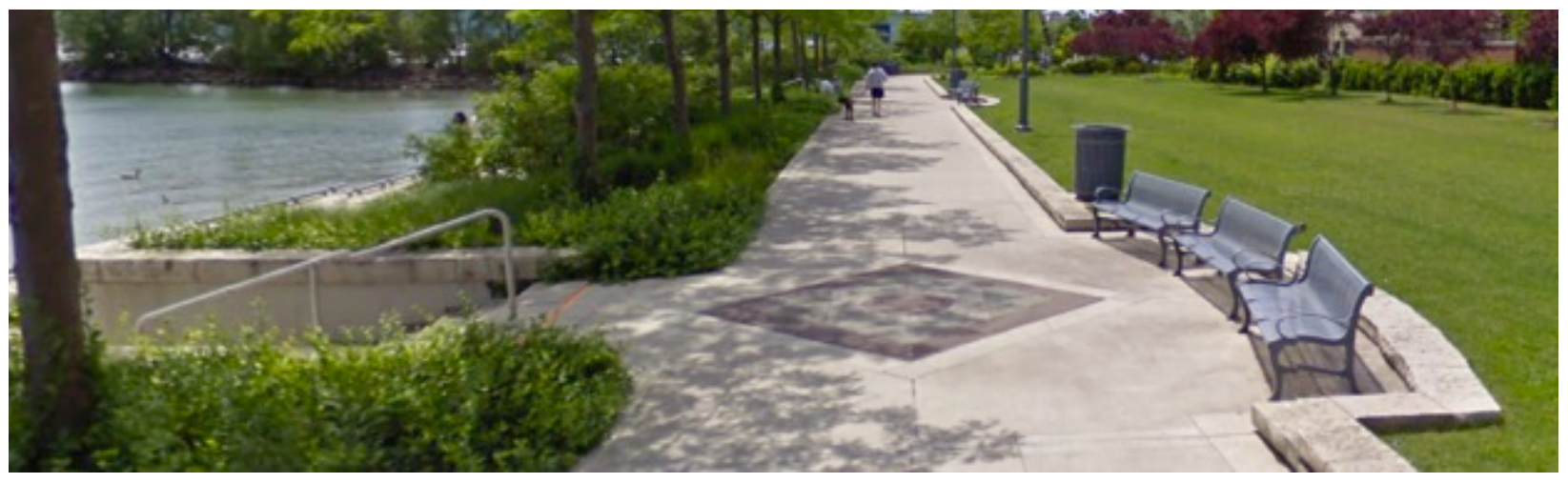

Source: GoogleMaps (2013) 
Figure 11: Benches provided at Harold E. Kennedy Park.

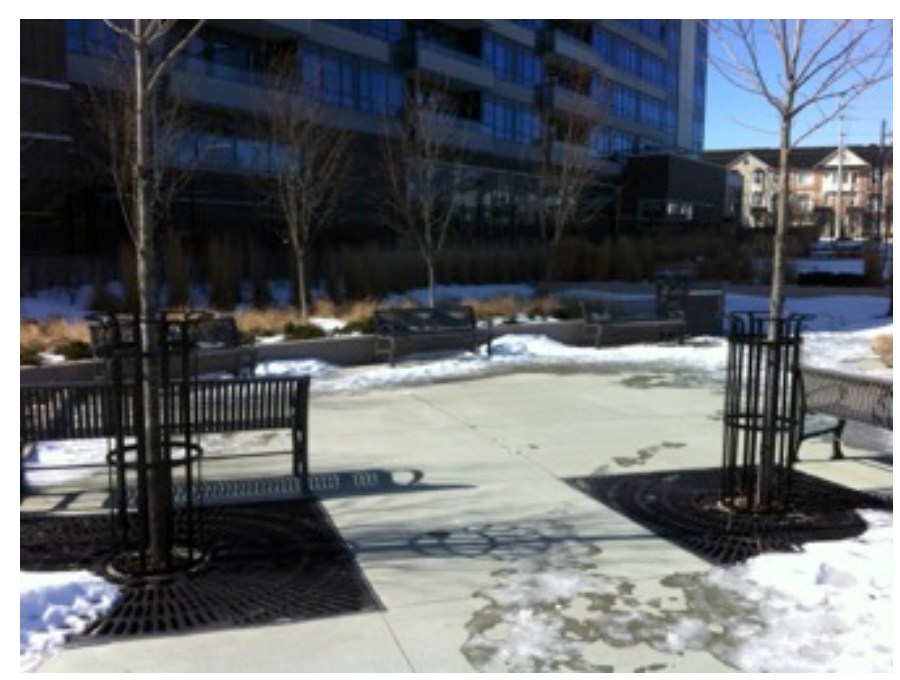

Source: Levine (2013)

Benches and resting places are of tremendous importance for seniors, as parks and trails, according to a local Port Credit urban planner, are an important component of Port Credit and are enjoyed by many of its senior residents (personal communication, March 19 2013). Furthermore, it was found through the City of Mississauga's Official Plan that public parks and walking trails are crucial in the lives of the residents and plays a role in the environmental and social health of the city. This is seen to be in line with the literature, as Hodge (2008) suggested that accessible walking trails are important to seniors. Section 6.3.3.3 of the Official Plan states "Public parkland will be designed to allow access for a variety of complementary activities through interconnections of pathways, a multi-use recreational trail and the public parkland network and to provide a safe and accessible environment through development of clear sight-lines, openness and visible entrances that can be achieved by maximizing street frontages where possible (2011, p. 6-16). 
Paths and trails are a vital aspect of the Port Credit neighbourhood (key informant, personal communication, March 15, 2013). Seeing as how the community is located directly adjacent to the waterfront, trails along the water's edge provide beautiful sightlines and vistas (see figure 12).

Figure 12: Waterfront trail

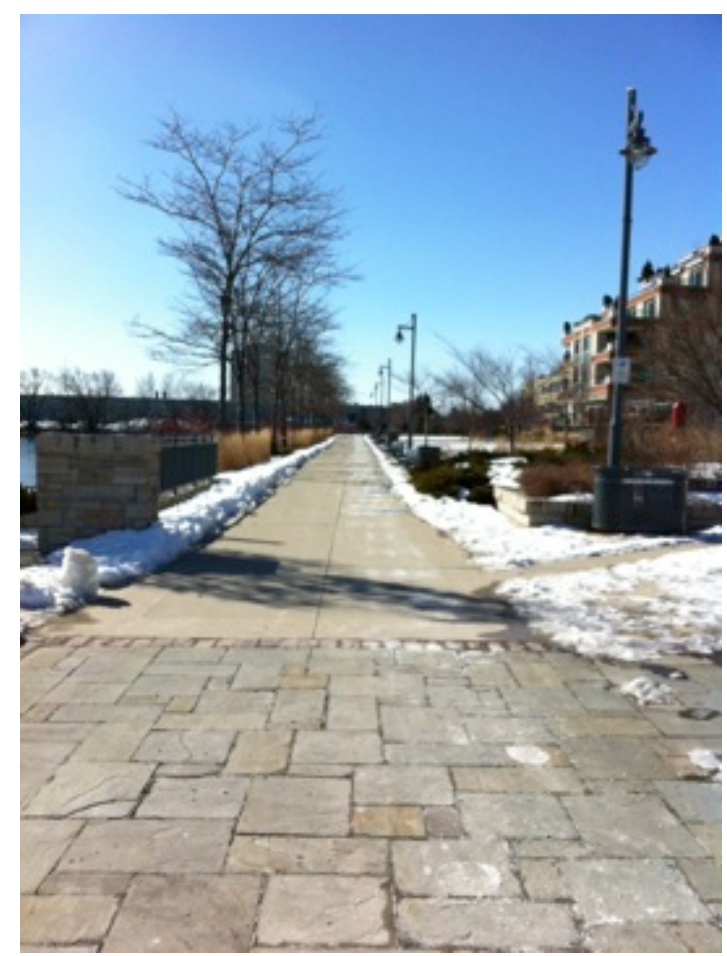

Source: Levine (2013)

These public amenities also provide the opportunity for seniors to exercise and benefit from walking's associated health impacts. The Accessibility Design Handbook speaks to paths and trails and prescribes that they should be barrier-free and should be located so as to encourage participation from the widest possible range of users (2007, p. 2-33). Section 8.2.4 'Active Transportation' in the City of Mississauga's Official Plan also speaks to paths and trails. Section 8.2.4.5 declares that sidewalks or multi use trails will be provided for all new roads and thus demonstrates the city's desire to get its residents active, by providing the necessary 
infrastructure. Moreover, section 8.2.4.6 discusses the importance of such sidewalks and trails in proximity to public transit stops. Upon site visits, it was confirmed that all transit stops, at least those within a 500 meter radius of Port Credit Village (figure 5), were located in areas where sidewalks were present.

The issue of smooth surfaces and ramps, as brought up in the literature by Moore \& Pacey (2004, in Hodge, 2008) is also addressed in the Accessibility Design Handbook (2007). In section 2.4.1 Ramps/ Cuts, it is suggested that "curb ramps should be designed to provide maximum utility to wheelchair and mobility equipment users, without creating additional hazards for people who have low or no vision" (p. 2-18). Evidence of this type of intervention can be seen just outside Port Credit Village, at the intersection of Lakeshore Road East (figure 13). This intersection has clearly marked pedestrian crossing road treatment and has smooth ramp access at all four corners, free from any obstruction.

Figure 13. Accessible ramp design at intersection of Lakeshore Road East and EImwood Avenue North

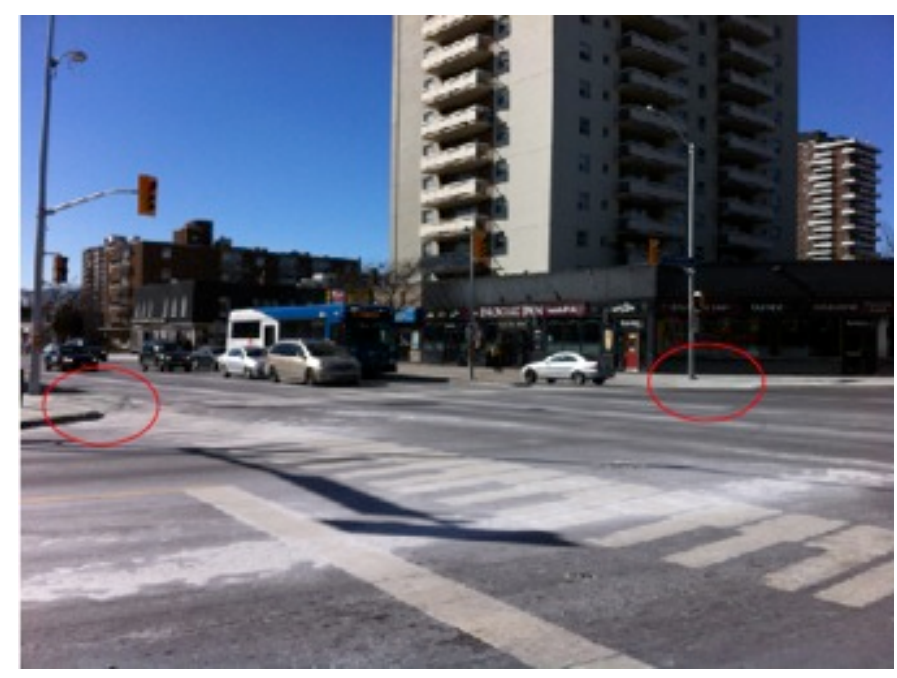

Source: Levine (2013) 
According to the WHO (2007) checklist, access to public washrooms is another critical aspect required in order to be considered senior friendly. It was found upon site visits that there is access to public washrooms at the GO transit station. This is a strategic positioning of public washrooms at an area of high level of pedestrian activity. The checklist further recommends the location of public toilets near areas of high senior uses, such as parks and city squares. The City of Mississauga Accessibility Design Handbook (2007) states under section 2.5.3 that picnic areas should be located within 180 meters of a public restroom and section 3.3.4 further demands that all restroom facilities be accessible, providing more space to individuals with physical disabilities and/ or using personal mobility devices. This goes to demonstrate both the actual physical installation of public washrooms and the policy behind its strategic location. 


\section{Conclusion}

As has been presented in this paper, the aging population will have dramatic impact on the overall make up of the global population. This will have consequential effects on the future of the urban built environment of cities. The research for this paper has found several key initiatives that the City of Mississauga, Ontario is promoting in making their urban built environment friendlier to seniors. The Transit Oriented Development of Port Credit was demonstrated to be a clear example of a more dense and compact built environment. The shift from single family, low-density housing isolated from services and amenities has been replaced by townhouses and mid-rise apartment buildings located in close proximity to places such as grocery stores and medical offices. Furthermore, the legalization of secondary suites can allow a more affordable housing alternative and allow seniors to age-in-place. The transportation network is also shifting away from being dominated by the private automobile and is being replaced with a network that promotes the use of public transit and active transportation. There is an importance placed on clean parks and walking trails. Moreover, the public realm is also being modified in that more attention is being paid to the accessibility of interior and exterior space. Due to the changing needs and capabilities of seniors, aspects of everyday life, which previously were not seen as being of importance, such as smooth surfaces and ramps, are now leading the way that spaces are being designed. By taking on projects such as studying neighbourhoods that are experiencing drastic demographics changes, such as those seen in Port Credit, there is much to be learned on how local governments are dealing and planning to deal with the issues related to an aging population. 


\section{Lessons Learned \& Recommendations}

After completing the research, there are a few critiques or limitations that should be acknowledged. This research looked simply at three particular issues with regards to senior friendly cities. As noted in the WHO (2007) Guide to Global Age Friendly Cities, there are eight areas of research that could potentially be discussed. If another researcher were to conduct more thorough research in this area, then perhaps looking into issues such as civic participation and employment, social participation, respect and social inclusion, and communication and information would add more insight and diversity to the topic. Also, the results of the research were gathered through documents, developers and members of the local government but did not include seniors themselves. Seniors' views were presented in the research by others noted in the literature review. There could definitely be merit in speaking to seniors who live in the area in order to get more insight into the positive and negative aspects of particular initiatives and areas of inaccessibility. If others chose to study the issue of senior friendly cities, more emphasis on the previous suggested topics could allow a more thorough understanding of a wider array of issues. The following recommendations stem from issues discussed in the text and which are thought to be of most importance for neighbourhoods such as Port Credit. Here we highlight the promotion of transit oriented development, the application of adaptable housing design for both

old and new developments and the inclusion of seniors within the community in identifying areas of inaccessibility.

\section{Continue to promote TOD developments}

The success of Smart Growth and Transit Oriented Development projects such as Port Credit Village in terms of increased density, transit use and walkability is a clear indicator of how this 
type of development will be beneficial to seniors in the short and long term. This design breaks from traditional suburban sprawl and provides seniors and many other previously disadvantaged groups with a newfound independence within the city. By continuing to promote projects that provide similar design principles and benefits, this will lend to an improved lifestyle for seniors. This recommendation seems appropriate for certain brownfield redevelopments in Port Credit such as the contaminated Imperial Oil Limited Site and Canada Lands Company Land Site. Located to the west of Port Credit Village, these two parcels of land have the capability of achieving similar levels of success if developed with seniors in mind.

\section{Promote the application of adaptable housing designs for new development}

As it was found that the senior population will be growing substantially throughout the Peel Region over the next two decades, especially in the Port Credit neighbourhood, and that the City of Mississauga is promoting aging in place through their action plan policies, it is recommended that at least a portion of all new development be designed in a way that can be easily adaptable to the changing capabilities of the users. Whether it be through the implementation of housing design guideline, or through the utilization of the principles of Flex Housing (CMHC, 2006) techniques, there should be some kind of policy or program in place that recognizes and seeks to address the future change in needs and capabilities of aging residents within the household environment, over time. Moreover, further research into modifying the building code to allow for more senior friendly housing design should be studied. 


\section{Conduct a survey aimed at seniors, to obtain more detailed information regarding barriers to accessibility.}

Considering that one of the weaknesses of this research paper is that it did not get information regarding accessibility directly from the senior residents of Port Credit themselves, it is suggested that this type of initiative is undertaken in order to address issues that may have fallen through the cracks of the method of this paper. By including seniors into the method of data collection, it would ideally bring to light certain issues that may not be self-evident. Furthermore, this would also act as an effort to engage seniors in civic participation, which in itself is one of the eight topic areas in the WHO (2007) checklist. 


\section{Works Cited}

American Association for Retired People. (2005). Beyond 50.05; a report to the nation on livable communities: creating environments for successful aging. Retrieved on October $2^{\text {nd }} 2012$ from: http://assets.aarp.org/rgcenter/il/beyond_50_communities.pdf

Australian Government. (2011). Caring for older Australians - an inquiry report - Chapter: 12 age-friendly housing and retirement villages. Retrieved on October $2^{\text {nd }} 2012$ from: http://www.pc.gov.au/projects/inquiry/aged-care/report

BurlingtonSeniors Age Friendly Task Force. (2009). Project Description. Retrieved on Macrh $28^{\text {th }} 2013$ from: http://afc.uwaterloo.ca/PDF/Burlington\%20-\%20word.pdf

City-data. (2013). Retrieved on April $11^{\text {th }} 2013$ from: http://www.city-data.com/forum/generalu-s/1076773-asian-american-statistical-portrait-12.html

City of Mississauga. (1999). Port Credit community profile. Retrieved on October $10^{\text {th }} 2012$ from: http://www5.mississauga.ca/research_catalogue/B-29_portcr1.PDF

City of Mississauga. (2004). Port Credit community profile. Retrieved on October $10^{\text {th }} 2012$ from: http://www.mississauga.ca/file/COM/2001PortCredit.pdf

City of Mississauga. (2007).Accessibility Design Handbook. Retrieved on March $21^{\text {st }} 2013$ from: http://www.mississauga.ca/file/COM/Accessibility_DesignHandbook_2ndEdition.pdf

City of Mississauga. (2007). Corporate report: general committee: older adult plan (Part One Framework)

City of Mississauga. (2007). Amendment no. 25: Port Credit district land use map. Retrieved on April $11^{\text {th }} 2013$ from: http://www6.mississauga.ca/onlinemaps/planbldg/missplan/Amend25/portcred.pdf

City of Mississauga. (2008). Older Adult Plan. Retrieved on October $17^{\text {th }}$ from: http://www.mississauga.ca/file/COM/Older_Adult Plan.pdf

City of Mississauga. (2009). Action Plan. Retrieved on October $17^{\text {th }} 2012$ from: http://www.mississauga.ca/portal/strategicplan/plan

City of Mississauga. (2011). Mississauga Official Plan (2011). Retrieved on March $21^{\text {st }} 2013$ from: http://www.mississauga.ca/portal/residents/mississaugaofficialplan

City of Mississauga. (2012). Port Credit Local Area Plan (DRAFT). Retrieved on October $20^{\text {th }}$ from:

http://www6.mississauga.ca/onlinemaps/planbldg/LakeviewPortCredit/DraftPortCreditLo calAreaPlanDocumentJanuary2012.pdf

City of Mississauga. (2012). Housing choices: second unit review. Retrieved on March $28^{\text {th }} 2013$ from: 
http://www5.mississauga.ca/agendas/planning/2013/02_25_13/Item01HousingChoices.p df

City of Mississauga. (2013). Public Meeting - housing choices: second units implementation strategy. Retrieved on March $28^{\text {th }} 2013$ from:

http://www5.mississauga.ca/agendas/planning/2013/02_25_13/Item01HousingChoices.p df

City of Toronto. (2012). A healthy Toronto by design report: Road to health: improving walking and cycling in Toronto. Retrieved on April $11^{\text {th }} 2013$ from: http://www.toronto.ca/health/hphe/pdf/roadtohealth.pdf

CMHC. (2006). CMHC FlexHousing. Retrieved on December $4^{\text {th }} 2012$ from: http://www.peelregion.ca/housing/provider/advisory/reports/pdf/forum/CMHC.pdf

CMHC. (2007). Transit oriented development case study: Port Credit village, Mississauga, Ontario. Retrieved on November $24^{\text {th }} 2012$ from: http://www.cmhcschl.gc.ca/en/inpr/su/sucopl/upload/65512-W.pdf

CMHC. (2008). Impacts of the aging of the Canadian population on housing and communities. Retrieved on October $2^{\text {nd }} 2012$ from: https://www03.cmhcschl.gc.ca/catalog/productDetail.cfm?cat=143\&itm=10\&lang=en\&fr=1350425061292

CMHC. (2012). Housing for older Canadians: the definitive guide to the over- 55 market Volume 1 understanding the market. Retrieved on October $15^{\text {th }} 2012$ from: http://www.cmhc-schl.gc.ca/odpub/pdf/67514.pdf

Dychwald, K. \& Flower, J. (1990). Age wave: how the most important trend of our time will change your future. Bantam Books

Edwards, N. C. \& Speer, B. A. (2010). Changing the building code through intersectoral and interdisciplinary efforts: a call to action. Retrieved on April $11^{\text {th }} 2013$ from: http://www.rrasp-phirn.ca/images/stories/docs/workingpaperseries/building-codesreport.pdf

Efroymson, D., Thanh Ha, Tran Thi Kieu., Thu Ha, P. (2009). Public spaces: how they humanize cities. Retrieved on March $24^{\text {th }} 2013$ from: http://www.healthbridge.ca/Public\%20Spaces_How\%20they\%20Humanize\%20Cities.pd $\underline{f}$

Fisker, C. E. (2011). End of the Road: loss of (auto)mobility among seniors and their altered mobilities and networks - a case study of a car-centric Canadian city and a Danish city. Published doctoral dissertation, University of Aalborg - Denmark

Fisker, C. E. (2012). Glimpses of motility of the networked self across the life course. In Vannini, P., Budd, L., Jensen, O. B., Fisker, C. \& Jiron, P. Technologies of mobility in the Americas. New York,: Peter Lang Publishing Group

Foot, D.K. (1996). Boom bust \& echo: how to profit from the coming demographic shift. Macfarlane Walter \& Ross 
GEA. (2012). Senior care. Retrieve on April $11^{\text {th }} 2013$ from: http://greateredmontonalliance.com/?p=31

Google Maps (2013). Port Credit. Retrieved on March $5^{\text {th }} 2013$ from: www.maps.google.com

Growth Plan for the Greater Golden Horseshoe. (2006). Places to grow. Retrieved on December $4^{\text {th }} 2012$ from: https://www.placestogrow.ca/content/ggh/plan-cons-english-all-web.pdf

Hamilton Council on Aging. (2010). Hamilton: a city for all ages. Retrieved on March $28^{\text {th }} 2013$ from:

http://www.coahamilton.ca/pdf/Hamilton,\%20A\%20City\%20for\%20ALL\%20Ages.pdf

Hemson Consulting Ltd. (2003). Growth in a maturing community - City of Mississauga population, household and employment forecasts 2001 - 2031. Retrieved on September $28^{\text {th }} 2012$ from: http://www.mississauga.ca/file/COM/GrowthbyHemson.pdf

Heritage Mississauga. (2009). http://www.heritagemississauga.com/page/Port-Credit

Hodge, G. (2008). Demographic and planning perspectives on aging in Canada. Plan Canada. 48. 3. Pp. 22 - 24. Retrieved on October $2^{\text {nd }} 2012$ from: ProQuest database.

Hodge, G. (2008). The geography of aging: preparing communities for the surge in senior. McGill - Queens University Press

Holeywell, R. (2012). How Will Boomers Reshape U.S. Cities? Retrieved on October $6^{\text {th }}$, 2012 from: http://www.governing.com/generations/government-management/gov-how-willboomers-reshape-cities.html

Human Resources and Skills Canada. (2011). Disability in Canada: A 2006 Profile: Section 7: Seniors (aged 65 and over). Retrieved on March $9^{\text {th }} 2013$ from: http://www.hrsdc.gc.ca/eng/disability_issues/reports/disability_profile/2011/page07.shtm 1

Kennedy, K. (2010). The city of 2050 - an age-friendly, vibrant, intergenerational community. Journal of American Society on Aging. 34. 3. Pp. 70 - 75. Retrieved on October $15^{\text {th }} 2012$ from ProQuest Database.

Levine, B. (2013). Site visit to Port Credit (photos)

MacEwen, A. (2012).

http://www.policyalternatives.ca/sites/default/files/uploads/publications/National\%20Offi ce/2012/04/WorkingAfter65.pdf

Manheimer, R. J. (2009). Creating meaningful senior friendly spaces. Generations. 33. 2. Pp. 60 - 65. Retrieved on October $15^{\text {th }} 2012$ from ProQuest Database.

Ontario Ministry of Energy and Infrastructure .(2009). Port credit village: phase 1. Urban Form Case Studies. Retrieved on November $1^{\text {st }} 2012$ from:

http://www.ontla.on.ca/library/repository/mon/23012/297301.pdf 
Ontario Ministry of Finance. (2012). Population by five-year age group, 2011-2036 - Reference scenario - Census divisions in the Greater Toronto Area. Retrieved on November $1^{\text {st }}$, 2012 from:

http://www.fin.gov.on.ca/en/economy/demographics/projections/table10gta.html

Peel Advisory Working Group on Older Adult's Housing. (2004). Opportunities in older adult's housing forum for developers and builders. Retrieved on October $16^{\text {th }} 2012$ from: http://www.peelregion.ca/housing/provider/advisory/reports/pdf/forum/AWGbuilders.pdf

Plouffe, L., \& Kalache, A. (2010). Towards Global Age Friendly Cities: Determining Urban Feature that Promote Active Aging. Journal of Urban Health , 87 (5), 733-739. Retrieved on October $1^{\text {st }} 2012$ from:

Portraits of Peel. (2012). The senior population (65+ years) by Peel neighbourhoods, 2006. Retrieved on October $1^{\text {st }} 2012$ from: http://www.portraitsofpeel.ca/pdf/TGP/2006/maps/seniors2006-revised.pdf

Provincial Policy Statement, Ontario. (2005).

Public Health Agency of Canada. (2010). The Chief Public Health Officer's Report on The State of Public Health in Canada 2010: Chapter 3: The Health and Well-being of Canadian Seniors. Retrieved on March $9^{\text {th }} 2013$ from: http://www.phac-aspc.gc.ca/cphorsphcrespcacsp/2010/fr-rc/cphorsphc-respcacsp-06-eng.php

Pynoos. J., Caraviello. C \& Cicero. C. (2009). Lifelong housing: the anchor in aging-friendly communities. Journal of American Society of Aging. 33, 2. Pp. 26 - 32. Retrieved from ProQuest Database on October $15^{\text {th }} 2012$.

Regional Municipality of Peel. (1997). Housing needs and options of older adults in Peel Region background report. Retrieved on November $5^{\text {th }} 2012$ from: http://www.peelregion.ca/housing/provider/advisory/reports/pdf/awg-solutions.pdf

Rosenbloom, S. (2003). The mobility needs of older Americans: implications for transportation reauthorization. Retrieved on October $27^{\text {th }} 2012$ from: http://www.brookings.edu/research/reports/2003/07/transportation-rosenbloom

Scharlach, A. E. (2009). Creating Aging-Friendly Communities. Retrieved on September $28^{\text {th }}$ from: from http://search.proquest.com.ezproxy.lib.ryerson.ca/docview/212231825/fulltextPDF?accou ntid $=13631$

Statistics Canada (2006). 5350504.01 \& 5350504.02 Community profile 2006. Retrieved on October $28^{\text {th }} 2012$ from: http://www12.statcan.ca/census-recensement/2006/dp$\mathrm{pd} /$ prof/92-591/index.cfm

Statistics Canada. (2006). A Portrait of Seniors in Canada. Retrieved on October $13^{\text {th }} 2012$ from: http://www.statcan.gc.ca/pub/89-519-x/89-519-x2006001-eng.pdf 
Statistics Canada. (2011). 5350504.01 \& 5350504.02 Community profile 2011. Retrieved on October $28^{\text {th }} 2012$ from: http://www12.statcan.gc.ca/census-recensement/2011/dp$\mathrm{pd} /$ prof/index.cfm?Lang $=\mathrm{E}$

Stromberg, M. (2007). Growing old in a car-centric world: Americans love their automobiles. What does that mean for an aging nation? Planning. 73, 10. Pp. $6-11$. Retrieved on October $11^{\text {th }}$ from EBSCOHOST database.

Tornalty, R., Curran, D. (2003). Living it up: the wide range of support for smart growth in Canada promises more livable towns and cities. Alternatives Journal. 29. 3. Pp. $10-18$. Retrieved on October $15^{\text {th }} 2012$ from ProQuest Database.

Traffic Safety Center. (2002). Why older adults don't walk. Retrieved on November $22^{\text {nd }} 2012$ from: http://safetrec.berkeley.edu/newsletter/Aug02/pedestrians.html

United Nations Center for Human Settlements. (1993). Improving the quality of life of elderly and disabled people in human settlements: Volume $1-$ A resource book of policy and programmes from around the world. Retrieved on October $14^{\text {th }} 2012$ from: http://www.chs.ubc.ca/archives/files/HS-284.pdf

World Health Organization. (2007). Global age-friendly cities: a guide. Retrieved September $28^{\text {th }}$ 2012 from:

http://www.who.int/ageing/publications/Global_age_friendly_cities_Guide_English.pdf

Ziebarth. A., Erm. H., Hwang. E. (2010). Designing Age-friendly communities. InformeDesign. 08. 02. Pp. 1-6. Retrieved on March $28^{\text {th }} 2013$ from: http://www.informedesign.org/_news/march_v08.pdf 


\section{Footnotes}

1 - Statistics Canada (2012). Housing for older Canadians: the definitive guide to the over-55 market. Vol 1. Retrieved on October $28^{\text {th }} 2012$, from: http://www.cmhcschl.gc.ca/odpub/pdf/67514.pdf

2 - Statistics Canada. (2011). 5350504.01 \& 5350504.02 Community profile 2011. Retrieved on October $28^{\text {th }} 2012$ from: http://www12.statcan.gc.ca/census-recensement/2011/dp$\mathrm{pd} /$ prof/index.cfm?Lang $=\mathrm{E}$ 